\title{
Gardenia jasminoides has therapeutic effects on L-NNA-induced hypertension in vivo
}

\author{
SHAOCHENG CHEN ${ }^{1-4}$, PENG SUN $^{1-4}$, XIN ZHAO $^{1-4}$, \\ RUOKUN YI ${ }^{1-4}$, JUN QIAN ${ }^{5}$, YANHONG SHI ${ }^{5,6}$ and RUI WANG ${ }^{5}$ \\ ${ }^{1}$ Chongqing Collaborative Innovation Center for Functional Food; ${ }^{2}$ Chongqing Engineering Research Center \\ for Functional Food; ${ }^{3}$ Chongqing Engineering Laboratory for The Research and Development of Functional Food; \\ ${ }^{4}$ Department of Biological and Chemical Engineering, Chongqing University of Education, Chongqing 400067; \\ ${ }^{5}$ School of Pharmacy, Shanghai University of Traditional Chinese Medicine, Shanghai 201210; \\ ${ }^{6}$ Chongqing Three Gorges Natural Medicine Research Institute, Chongqing 404000, P.R. China
}

Received September 2, 2016; Accepted March 3, 2017

DOI: $10.3892 / \mathrm{mmr} .2017 .6542$

\begin{abstract}
Gardenia jasminoides is a plant that has been used in traditional Chinese medicine. It has four key active components (genipin gentiobioside, geniposide, crocin 1 and crocin 2). The aim of the present study was to determine the anti-hypertension effects of Gardenia jasminoidesin vivo. The chemical composition of Gardenia jasminoides was determined using liquid chromatography. The anti-hypertensive effects of Gardenia jasminoides were determined by a $\mathrm{L}-\mathrm{N}^{\mathrm{G}}$-nitroarginine (L-NNA)-induced hypertension animal model. Both Gardenia jasminoides plants of the Jiangjin County variety (CJGJ) and the Lichuan City variety (HLGJ) were used. HLGJ contained more geniposide than CJGJ. L-NNA was used to induce hypertension in mice, and the mice were subsequently treated with CJGJ and HLGJ. The Gardenia jasminoides-treated mice exhibited lower systolic (SBP), diastolic (DBP) and mean blood pressure (MBP) than the experimental control mice. Additionally, HLGL has a more potent effect on SBP, MBP and DBP than CJGJ. Following Gardenia jasminoides treatment, the nitric oxide contents in serum, heart, liver, kidney and stomach of mice were higher than the L-NNA-induced control mice, and the malondialdehyde contents were lower; the levels in HLGJ-treated mice were closer to those normal
\end{abstract}

Correspondence to: Professor Rui Wang, School of Pharmacy, Shanghai University of Traditional Chinese Medicine, 1200 Cailun Road, Shanghai 201210, P.R. China

E-mail:wangelle@hotmail.com

Professor Yanhong Shi, Chongqing Three Gorges Natural Medicine Research Institute, 165 Qingming Road, Chongqing 404000, P.R. China

E-mail: yhs_lucky@163.com

${ }^{*}$ Contributed equally

Key words: Gardenia jasminoides, hypertension, expression, L-N $\mathrm{N}^{\mathrm{G}}$-nitroarginine, nitric oxide synthase mice than the levels in CJGJ-treated mice were. Serum levels of endothelin-1 and vascular endothelial growth factor were reduced by HLGJ treatment in hypertensive mice, whereas the calcitonin gene-related peptide level was raised. Reverse transcription-polymerase chain reaction analysis of mouse heart and vessel tissue demonstrated that HLGJ-treated mice exhibited higher heme oxygenase-1, neuronal nitric oxide synthase (nNOS), endothelial NOS, Bax, caspase-3, caspase-8, caspase-9 mRNA expression levels and lower adrenomedullin, receptor activity modifying protein, interleukin-1 $\beta$, tumor necrosis factor- $\alpha$, inducible NOS, Bcl-2, monocyte chemoattractant protein-1, nuclear factor- $\kappa \mathrm{B}$ and matrix metalloproteinase-2 and -9 mRNA expression compared with control hypertensive mice and CJGJ-treated mice. In conclusion, Gardenia jasminoides has anti-hypertensive effects, and these effects may be associated with the active component, geniposide.

\section{Introduction}

In traditional Chinese medicine, the pathogenesis of hypertension is mainly attributed to liver, kidney, heart and spleen dysfunction, that cause an imbalance in the body (1). Traditional Chinese treatments focus on the etiology and pathology of hypertension, and aim, via restoring the function of the immune system and other organs, to eradicate the underlying causes of hypertension. Traditional Chinese formulas do not produce serious adverse events, such as those associated with antihypertensive agents used in western medicine (2). Traditional Chinese treatments aim to repair the damages induced by increased blood pressure, via facilitating blood circulation, alleviating blood stasis, regulating blood lipid contents and restoring the blood pressure regulatory mechanisms (3).

Gardenia jasminoides Ellis is an edible plant that has also been used in traditional Chinese medicine (4). In traditional Chinese medicine, Gardenia jasminoides has been used for its liver- and gallbladder-protecting properties, in the treatment of contusions to stop bleeding and reduce swelling, as well as in the treatment of diabetes (5). Previous studies on the chemical composition of Gardenia jasminoides have reported 
that iridoid glycosides, diterpenoids and organic acid esters are among its main ingredients $(5,6)$. More than 20 different types of iridoid glycosides have been identified in Gardenia jasminoides extracts, including genipin 1-gentiobioside and gardenoside. Among Gardenia jasminoides diterpenoids, crocin 1 and crocin 2 are the most abundant. Genipin 1-gentiobioside, gardenoside, crocin 1 and crocin 2 have been suggested to mediate the biological actions of Gardenia jasminoides (7).

L-N $\mathrm{N}^{\mathrm{G}}$-nitroarginine (L-NNA) is an inhibitor of nitric oxide synthase (NOS), which can increase blood pressure by inhibiting NO production. L-NNA is often used in experimental hypertension models, as it can inhibit the endothelium-dependent relaxation of blood vessels $(8,9)$. When used in the induction of experimental hypertension, L-NNA potently inhibits NO production in vascular endothelium, whereas it also promotes vascular smooth muscle cell proliferation, and thus changes vascular structure, impairs endothelial function and increases arterial blood pressure (10). The present study employed an L-NNA-induced mouse model of hypertension to investigate the effects of Gardenia jasminoides on hypertension. The molecular mechanisms underlying the actions of Gardenia jasminoides were also examined, via the evaluation of serum levels of key proteins and the expression of related genes. Furthermore, the chemical composition of Gardenia jasminoides was analyzed in order to identify the main components responsible for its effects.

\section{Materials and methods}

Preparation of Gardenia jasminoides extracts. Gardenia jasminoides plants of the Jiangjin County variety (CJGJ) were purchased in Chongqing local markets (Jiangjin, China); Gardenia jasminoides plants of the Lichuan City variety (HLGJ) were purchased in Lichuan local markets (Hubei, China). The plants were authenticated using an ultraviolet spectrophotometer, ultraviolet absorption spectrum and thin layer chromatography by Dr Long Song (Department of Pharmacognosy, Shanghai University of Traditional Chinese Medicine, Shanghai, China). Gardenia jasminoides was stored at $-80^{\circ} \mathrm{C}$ and freeze-dried to produce a powder. A 20 -fold volume of $70 \%$ methanol was added to the powdered sample for the sonic extraction of Gardenia jasminoides components (power, $250 \mathrm{~W}$; frequency, $40 \mathrm{kHz}$ ). Methanol extracts were evaporated using a rotary evaporator (N-1100; Eywla, Tokyo, Japan).

Liquid chromatography. Standards for genipin 1-gentiobioside, gardenoside, crocin 1 and crocin 2 were prepared in $20 \mathrm{ml}$ volumetric flasks. Methanol was used to obtain stock solutions with concentrations of 1.03, 1.07, 0.103 and $1.02 \mathrm{mg} / \mathrm{ml}$. Standards were prepared by 5 -fold dilution of the stock solutions. A Waters ${ }^{\circledR}$ ACQUITY UPLC ${ }^{\circledR} \mathrm{BEH}$ C18 chromatography column $(2.1 \times 50 \mathrm{~mm}, 1.7 \mu \mathrm{m})$ was used (Waters China, Ltd., Shatin, Hong Kong). Acetonitrile (A) and $0.2 \%$ phosphoric acid solution (B) were used as the mobile phase during gradient elution (8-20\% A during 0-3 min, 20-35\% A during 3-8 min). The detection wavelength was $238 \mathrm{~nm}$ during 0-5 min and $440 \mathrm{~nm}$ during 5-8 $\mathrm{min}$. The flow rate was $0.3 \mathrm{ml} / \mathrm{min}$ and the column temperature was $30^{\circ} \mathrm{C}$. Sample volumes were $2 \mu \mathrm{l}$.
Animal experiment. A total of 40 male ICR mice (age, 7 weeks; body weight, 20-25 g) were purchased from the Experimental Animal Center of Chongqing Medical University (Chongqing, China). ICR mice were randomly assigned to the following four groups ( $\mathrm{n}=10 \mathrm{mice} / \mathrm{group}$ ): Normal group, control group, CJGJ group, HLGJ group. Mice in the control, CJGJ and HLGJ groups were treated with $700 \mathrm{mg} / \mathrm{kg} \mathrm{L-NNA}(2 \mathrm{ml})$ daily (Shanghai Golden Time Biological Technology Co., Ltd., Shanghai, China) via gavage for 20 days. Mice in the normal group were treated with normal saline $(2 \mathrm{ml})$ via gavage for 20 days. Following L-NNA treatment for 7 days, mice in the CJGJ and HLGJ groups were treated with $500 \mathrm{mg} / \mathrm{kg}$ CJGJ and HLGJ via gavage. On day 20, 45 min after L-NNA the systolic (SBP), diastolic (DBP) and mean blood pressure (MBP) were measured using the Tail-cuff method (MRBP non-invasive blood pressure meter, Shanghai Yuyan Instruments Co., Ltd., Shanghai, China). Subsequently, mice were sacrificed via $\mathrm{CO}_{2}$ inhalation and the heart, liver, kidney and stomach were collected. Blood and heart whole blood vessel samples were also obtained. The present study was approved by the Animal Ethics Committee of Chongqing Medical University.

Metabolite levels. NO (cat. no A012) and malondialdehyde (MDA; cat. no A003-1) levels in heart, liver, kidney and stomach tissue samples were determined using detection kits (Nanjing Jiancheng Bioengineering Institute, Nanjing, China). Serum NO (cat. no A012), MDA (cat. no A003-1), endothelin (ET)-1 (cat. no H093) and calcitonin gene-related peptide (CGRP; cat. no H217) levels were determined using the appropriate detection kits (Nanjing Jiancheng Bioengineering Institute). Serum vascular endothelial growth factor (VEGF; cat. no 111202; Beijing BLKW Biotechnology Co., Ltd., Beijing, China) and E-selectin (cat. no m1002207; Shanghai Enzyme-linked Biotechnology Co., Ltd., Shanghai, China) levels were assessed using an ELISA kit.

Reverse transcription-polymerase chain reaction ( $R T-q P C R)$. Total RNA was extracted from myocardial and vascular endothelial tissue samples using RNAzol reagent, (Invitrogen; Thermo Fisher Scientific, Inc., Waltham, MA, USA. The concentration of the extracted RNA was adjusted to $1 \mu \mathrm{g} / \mu \mathrm{l}$. Total RNA $(2 \mu \mathrm{l})$ was reverse transcribed into cDNA using $1 \mu \mathrm{l}$ each of oligo $(\mathrm{dT})_{18}$, RNase, deoxyribonucleotide triphosphate and M-MLV reverse transcriptase (Roche Diagnostics, Basel, Switzerland) in $5 \mathrm{X}$ buffer $(10 \mu \mathrm{l})$. RT was performed with incubation at $37^{\circ} \mathrm{C}$ for $120 \mathrm{~min}, 99^{\circ} \mathrm{C}$ for $4 \mathrm{~min}$ and $4^{\circ} \mathrm{C}$ for $3 \mathrm{~min}$. The primers used for PCR amplification of heme oxygenase (HO)-1, adrenomedullin (ADM), receptor activity modifying protein (RAMP) 2, interleukin (IL)-1 $\beta$, tumor necrosis factor (TNF)- $\alpha$, B-cell lymphoma-2 (Bcl-2), Bcl-2-associated $\mathrm{X}$ protein (Bax), caspase-3, caspase-8, caspase-9, monocyte chemoattractant protein (MCP)-1, nuclear factor- $\kappa \mathrm{B}$

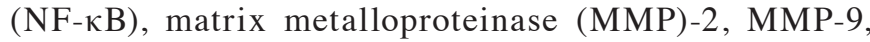
neuronal (n)NOS, endothelial (e)NOS and inducible (i)NOS are presented in Table I. GAPDH was used as an internal control. cDNA $(2 \mu \mathrm{l})$ was mixed with $1 \mu \mathrm{l}$ of each $10 \mu \mathrm{M}$ primer and $16 \mu \mathrm{l}$ of DNase-free water in a PCR premix tube (AccuPower ${ }^{\circledR}$ PCR PreMix; Bioneer Corporation, Daejeon, Korea) and PCR was performed in an automatic thermocycler (Bioneer Corporation) for 40 cycles of $94^{\circ} \mathrm{C}$ for $5 \mathrm{~min}, 58^{\circ} \mathrm{C}$ 
Table I. Primer sequences used for reverse transcription-quantitative polymerase chain reaction.

Gene Sequence

HO-1 F: 5'-GGAACTTTCAGAAGGGCCAG-3' R: 5'-GTCCTTGGTGTCATGGGTCA-3'

ADM F: 5'-GCTGGTTTCCGTCGCCCTGATGT-3' R: 5'-CGTTGTCCTTGTCCTTATCTGTG-3'

RAMP2 F: 5'-GGACGGTGAAGAACTATGAG-3' R: 5'-ATCATGGCCAGGAGTACATC-3'

IL-1 $\beta \quad$ F: 5'-CTCCATGAGCTTTGTACAAGG-3' R: 5'-TGCTGATGTACCAGTTGGGG-3'

TNF- $\alpha$ F: 5'-CTCCCTCCAGAAAAGACACCAT-3' R: 5'-ATCACCCCGAAGTTCAGTAGACAG-3'

nNOS F: 5'-GAATACCAGCCTGATCCATGGAA-3' R: 5'-TCCTCCAGGAGGGTG' TCCACCG CATG-3

eNOS F: 5'-GGAGAGGCTGCATGACATTG-3' R: 5'-GGTAGAGCCATAGTGGAATGAC-3'

iNOS F: 5'-AGAGAGATCGGGTTCACA-3' R: 5'-CACAGAACTGAGGGTACA-3'

Bax F: 5'-AAGCTGAGCGAGTGTCTCCGGCG-3' R: 5'-CAGATGCCGGTTCAGGTACTCAGTC-3'

Bcl-2 F: 5'-CTCGTCGCTACCGTCGTGACTTGG-3' R: 5'-CAGATGCCGGTTCAGGTACTCAGTC-3'

Caspase-3 F: 5'-CAAACTTTTTCAGAGGGGATCG-3' R: 5'-GCATACTGTTTCAGCATGGCA-3'

Caspase-8 F: 5'-CCCCACCCTCACTTTGCT-3'

R: 5'-GGAGGACCAGGCTCACTTA-3'

Caspase-9 F: 5'-GGCCCTTCCTCGCTTCATCTC-3' R: 5'-GGTCCTTGGGCCTTCCTGGTAT-3'

MCP-1 F: 5'-CACGTCGTAGCA AACCACCAA-3' R: 5'-GTTGGTTGTCTTTGAGATCCAT-3' NF-кB F: 5'-CACTTATGGACAACT'ATGAGGTCTC TGG-3

R: 5'-CTGTCTTGTGGACAACGCAGTGGAAT' TTTAGG-3

MMP-2 F: 5'-CTTCTTCAAGGACCGGTTCA-3' R: 5'-GCTGGCTGAGTACCAGTA-3'

MMP-9 F: 5'-TGGGCTACGTGACCTATGAC-3' R: 5'-GCCCAGCCCACCTCCACTCC-3'

GAPDH F: 5'-CGGAGTCAACGGATTTGGTC-3' R: 5'-AGCCTTCTCCATGGTCGTGA-3'

HO, heme oxygenase; ADM, adrenomedullin; RAMP, receptor activity modifying protein; IL, interleukin; TNF, tumor necrosis factor; n, neuronal; NOS, nitric oxide synthase; e, endothelial; i, inducible; Bax, B-cell lymphoma $(\mathrm{Bcl})$-2-associated $\mathrm{X}$ protein; Bcl-2, B-cell lymphoma-2; MCP, monocyte chemoattractant protein; $\mathrm{NF}-\kappa \mathrm{B}$, nuclear factor- $\kappa \mathrm{B}$; MMP, matrix metalloproteinase.

for $30 \mathrm{sec}$ and $72^{\circ} \mathrm{C}$ for $90 \mathrm{sec}$, followed by a $10 \mathrm{~min}$ cycle at $95^{\circ} \mathrm{C}$. Then these PCR products were resolved by $1.2 \%$ agarose gel electrophoresis using $1 \%$ ethidium bromide. Gene expression was semi-quantitatively analyzed using ImageJ software version 1.44 (National Institutes of Health, Bethesda, MD, USA) and normalized to GAPDH, as previously described (11). The following formula was used to calculate the fold-ratio: Target gene expression/GAPDH x control numerical value (control fold ratio=1).

Statistical analysis. The statistical significance of the difference between groups was assessed by one-way analysis of variance followed by a post hoc Duncan's test for multiple comparisons. Data are expressed as the mean \pm standard deviation of three independent experiments. The analysis was performed using SAS statistical software version 9.1 (SAS Institute Inc., Cary, NC, USA). $\mathrm{P}<0.05$ was considered to indicate a statistically significant difference.

\section{Results}

Gardenia jasminoides chemical constituents. Genipin 1-gentiobioside, gardenoside, crocin 1 and crocin 2 standards were dissolved in methanol. Genipin 1-gentiobioside standard solutions were adjusted to $1.0300,0.5150,0.2575,0.1288,0.0644$, $0.0322 \mathrm{mg} / \mathrm{ml}$; gardenoside standard solutions were adjusted to $1.0700,0.5350,0.2675,0.1338,0.0669,0.0334 \mathrm{mg} / \mathrm{ml}$; crocin 1 standard solutions were adjusted to $0.2575,0.1288$, $0.0644,0.0322,0.0161$ and $0.0080 \mathrm{mg} / \mathrm{ml}$; and crocin 2 standard solutions were adjusted to $0.0638,0.0319,0.0159,0.0080$, $0.0040,0.0020 \mathrm{mg} / \mathrm{ml}$. The standards were assessed using liquid chromatography and standard curves were determined. The following equations were used: Genipin 1-gentiobioside, $y=5 \times 10^{6} x+17,485$; gardenoside, $y=1 \times 10^{7} x+96,992$; crocin $1, y=4 \times 10^{7} x+10,1764$; and crocin $2, y=4 \times 10^{7} x-784.4$. Subsequently, genipin 1-gentiobioside, gardenoside, crocin 1 and crocin 2 contents of the two Gardenia jasminoides varieties were chromatographically determined according to the standard curves (Fig. 1). The chemical compositions of CJGJ and HLGJ are presented in Table II.

Blood pressure. Mice in the control group exhibited the highest SBP, DBP and MBP following L-NNA treatment, whereas normal mice exhibited the lowest blood pressure measurements (Table III). Treatment with CJGJ and HLGJ appeared to significantly reduce SBP, DBP and MBP in L-NNA-treated mice compared with L-NNA-treated control mice $(\mathrm{P}<0.05)$. The effect of HLGJ on blood pressure was significantly greater compared to the effects of CJGJ (Table III).

Serum and tissue NO levels. Normal mice had the highest serum and heart, liver, kidney and stomach tissue NO levels, whereas control mice exhibited the lowest NO contents (Table IV). L-NNA-treated mice exhibited significantly increased serum and tissue NO contents following HLGJ and CJGJ treatment compared with control mice $(\mathrm{P}<0.05)$. $\mathrm{NO}$ contents in HLGJ-treated mice were closer to the NO contents of normal mice compared with in CJGJ-treated mice (Table IV).

Serum and tissue MDA levels. Following the induction of hypertension by L-NNA, control mice demonstrated the highest 

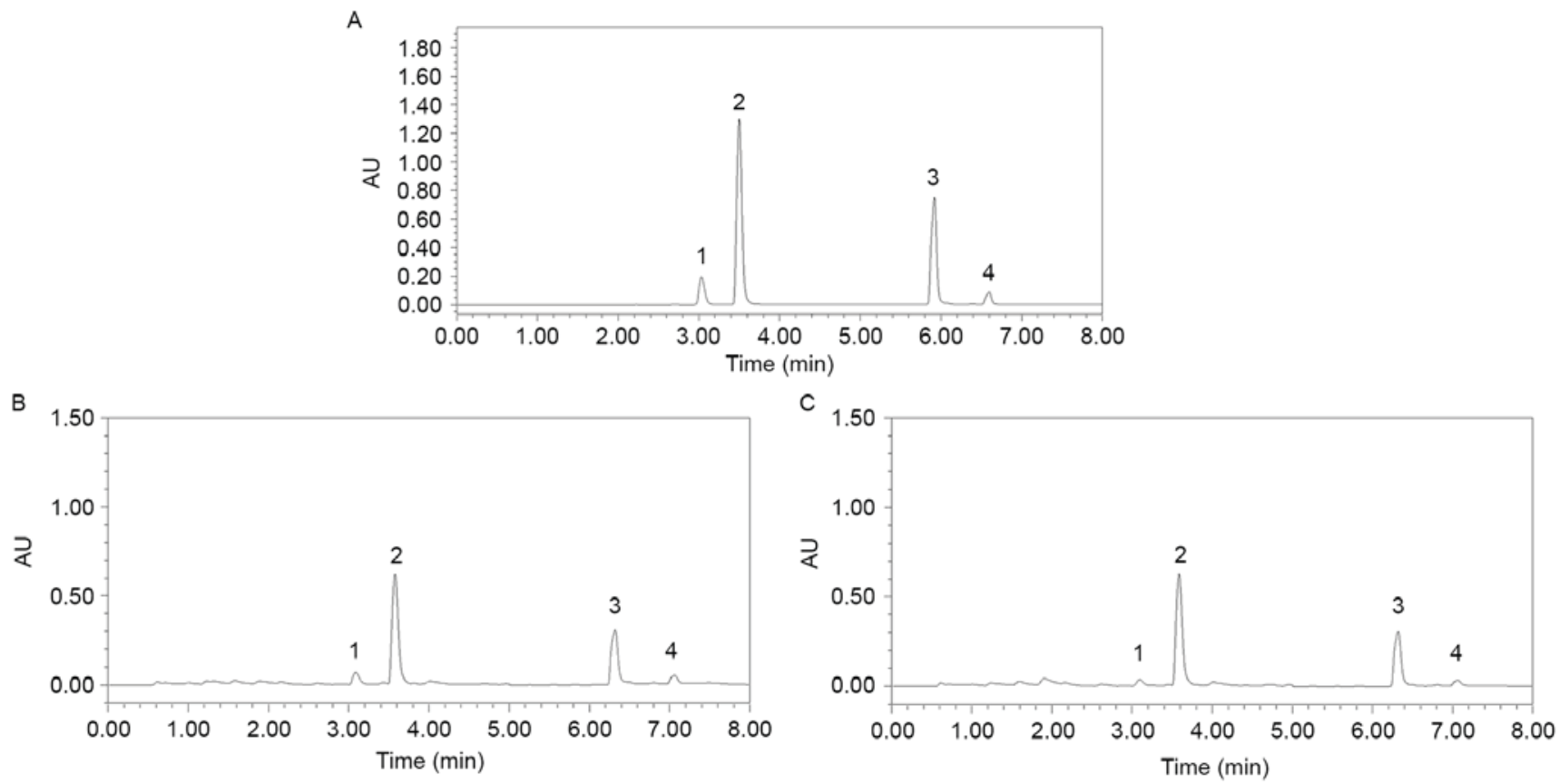

Figure 1. Analysis of the chemical composition of Gardenia jasminoides using liquid chromatography. (A) Standards of genipin 1-gentiobioside, gardenoside, crocin 1 and crocin 2 were analyzed. (B) Chemical composition of Gardenia jasminoides from Jiangjin County. (C) Chemical composition of Gardenia jasminoides from Lichuan City. Peaks correspond to: 1, Genipin gentiobioside; 2, gardenoside; 3, crocin 1; and 4, crocin 2.

MDA serum, heart, liver, kidney and stomach tissue contents (Table V). Treatment with CJGJ and HLGJ significantly reduced MDA serum and tissue levels in L-NNA-treated mice $(\mathrm{P}<0.05)$. MDA contents in HLGJ-treated mice were lower and closer to MDA contents of normotensive mice compared with in CJGJ-treated mice (Table V).

Serum ET-1, CGRP, VEGF and E-selectin levels. L-NNAinduced hypertensive mice (control) exhibited the highest ET-1, VEGF and E-selectin serum levels and the lowest CGRP serum levels among the groups (Table VI). Treatment with CJGJ and HLGJ significantly reduced ET-1, VEGF and E-selectin serum levels, and increased CGRP serum levels compared with L-NNA-treated control mice. HLGJ-treated mice demonstrated lower ET-1, VEGF and E-selectin and higher CGRP levels compared with CJGJ-treated mice, and these levels were closer to those reported in normal mice (Table VI).

HO-1, ADM and RAMP2 mRNA expression levels. HO-1 mRNA expression levels were the highest in myocardial and blood vessel tissue samples of normal mice (2.84- and 2.63-folds over control, respectively). Conversely, ADM and RAMP2 mRNA expression levels in normal mice were the lowest (ADM, 0.22- and 0.22-folds over control; RAMP2, 0.31- and 0.37-folds over control, in myocardial and endothelial samples, respectively). HJGJ-treated hypertensive mice exhibited reduced ADM and RAMP2, and increased HO-1 myocardial (ADM, 0.70-; RAMP2, 0.59-; and HO-1, 2.56-folds over control) and endothelial (ADM, 0.53-; RAMP2, 0.73-; and HO-1, 2.39-folds over control) mRNA expression levels compared with CJGJ-treated mice (ADM, 0.85- and 0.83-folds over control; RAMP2, 0.84- and 0.85-folds over control; HO-1, 1.51- and 1.83-folds over control, in myocardial and endothelial samples, respectively). HO-1, ADM and RAMP-2 mRNA expression levels in HJGJ-treated mice were closer to the levels reported in normal mice compared with in CJGJ-treated mice (Fig. 2).

$I L-1 \beta$ and TNF- $\alpha$ mRNA expression levels. Blood vessel samples isolated from control mice exhibited the highest IL-1 $\beta$ and TNF- $\alpha$ mRNA expression levels (Fig. 3). IL-1 $\beta$ and TNF- $\alpha$ mRNA expression levels were decreased in L-NNA-induced hypertensive mice following treatment with CJGJ (0.85- and 0.80 -folds over control, respectively) and HLGJ (0.64- and 0.57 -folds over control, respectively). IL-1 $\beta$ and TNF- $\alpha$ mRNA expression levels in HJGJ-treated mice were closer to the levels reported in normal mice (0.38- and 0.27-folds over control, respectively) compared with in CJGJ-treated mice (Fig. 3).

nNOS, eNOS and iNOS mRNA expression levels. Normal, and CJGJ- and HLGJ-treated mice demonstrated increased myocardial nNOS mRNA expression levels compared with control hypertensive mice (3.61-, 2.23- and 3.06-folds over control, respectively; Fig. 4A). In addition, nNOS mRNA expression levels in blood vessel samples isolated from normal (3.09-folds over control), CJGJ-(1.62-folds over control) and HLGJ-treated (2.68-folds over control) mice were increased compared with in control mice (Fig. 4B). Myocardial and endothelial eNOS expression levels in normal (2.07- and 8.22-folds over control, respectively), CJGJ-(1.31- and 5.79-folds over control, respectively) and HLGJ-treated (1.77- and 7.41-folds over control, respectively) mice were significantly upregulated compared with in control hypertensive mice. Conversely, myocardial and endothelial iNOS expression levels were significantly lower in normal (0.26- and 0.37-folds over control, respectively), CJGJ-(0.87- and 0.87-folds over control, respectively) and 
Table II. Analysis of the chemical composition of Gardenia jasminoides using liquid chromatography.

\begin{tabular}{lcccc}
\hline Sample & Genipin 1-gentiobioside $(\%)$ & Gardenoside $(\%)$ & Crocin 1 (\%) & Crocin 2(\%) \\
\hline CJGJ & 0.59 & 2.74 & 0.38 & 0.06 \\
HLGJ & 0.33 & 2.91 & 0.39 & 0.04 \\
\hline
\end{tabular}

CJGJ, Jiangjin County Gardenia jasminoides variety; HLGJ, Lichuan City Gardenia jasminoides variety.

Table III. Effects of treatment with Gardenia jasminoides on SBP, DBP and MBP in mice.

\begin{tabular}{lccc}
\hline Group & SBP $(\mathrm{mmHg})$ & DBP $(\mathrm{mmHg})$ & MBP $(\mathrm{mmHg})$ \\
\hline Normal & $101.7 \pm 3.2^{\mathrm{d}}$ & $82.0 \pm 2.1^{\mathrm{d}}$ & $70.2 \pm 1.7^{\mathrm{d}}$ \\
Control & $137.6 \pm 4.2^{\mathrm{a}}$ & $108.7 \pm 3.0^{\mathrm{a}}$ & $91.5 \pm 2.2^{\mathrm{a}}$ \\
CJGJ & $115.2 \pm 2.8^{\mathrm{b}}$ & $94.1 \pm 2.2^{\mathrm{b}}$ & $82.3 \pm 1.8^{\mathrm{b}}$ \\
HLGJ & $107.7 \pm 2.4^{\mathrm{c}}$ & $87.0 \pm 1.6^{\mathrm{c}}$ & $78.1 \pm 1.4^{\mathrm{c}}$ \\
\hline
\end{tabular}

\footnotetext{
${ }^{\mathrm{a}-\mathrm{d}}$ Mean values with different letters in the same column are significantly different, $\mathrm{P}<0.05$. Values are expressed as the mean \pm standard deviation. CJGJ, Jiangjin County Gardenia jasminoides variety; HLGJ, Lichuan City Gardenia jasminoides variety; SBP, systolic blood pressure; DBP, diastolic BP; MBP, mean BP; L-NNA, $\mathrm{L}-\mathrm{N}^{\mathrm{G}}$-nitroarginine.
}

HLGJ-treated (0.65- and 0.57-folds over control, respectively) mice compared with in control mice (Fig. 4).

Bax and Bcl-2 mRNA expression levels. Treatment with CJGJ and HLGJ was demonstrated to significantly upregulate Bax and downregulate Bcl-2 myocardial mRNA expression levels compared with control hypertensive mice (Fig. 5). Bax mRNA expression levels appeared to be higher in tissue samples isolated from HLGJ-treated mice (3.02-folds over control) compared with from CJGJ-treated mice (1.38-folds over control). Conversely, Bcl-2 mRNA expression levels appeared to be lower in HLGJ-treated tissue (0.23-folds over control) compared with in CJGJ-treated tissue (0.39-folds over control).

Caspase-3, caspase- 8 and caspase- 9 mRNA expression levels. Caspase-3, caspase- 8 and caspase- 9 mRNA expression levels in myocardial tissue of control hypertensive mice were the lowest (10.42-, 3.14- and 2.22-folds over control, respectively). HLGJ-treated hypertensive mice exhibited significantly increased caspase- 3 , caspase- 8 and caspase- 9 mRNA expression levels (4.58-, 1.79- and 1.48-folds over control, respectively) compared with mice in the control and CJGJ-treated groups (Fig. 6).

MCP-1 and NF-xB mRNA expression levels. Myocardial and endothelial MCP-1 and NF- $\mathrm{BB}$ mRNA expression levels were the lowest in normotensive (MCP-1,0.11- and 0.23-folds over control; NF- $\mathrm{KB}, 0.10$ - and 0.22-folds over control, respectively) and the highest in control hypertensive mice (Fig. 7). Treatment with HLGJ significantly downregulated
MCP-1 (0.31- and 0.54-folds over control, respectively) and $\mathrm{NF}-\kappa \mathrm{B}$ (0.31- and 0.41-folds over control, respectively) mRNA expression levels compared with CJGJ treatment (MCP-1, 0.53- and 0.72-folds over control; NF- $\kappa \mathrm{B}, 0.68$ - and 0.56 -folds over control, respectively) in heart and blood vessel tissue samples.

MMP-2 and MMP-9 mRNA expression levels. Control hypertensive mice demonstrated the highest MMP-2 and MMP-9 mRNA expression levels in myocardial and blood vessel samples. Treatment with CJGJ and HLGJ significantly downregulated the expression of MMP-2 and MMP-9 (Fig. 8). MMP-2 and MMP-9 mRNA expression levels in myocardial (0.34- and 0.54-folds over control, respectively) and blood vessel (0.27- and 0.09-folds over control, respectively) tissue samples isolated from HLGJ-treated mice were significantly reduced compared with in CJGJ-treated tissue samples.

\section{Discussion}

ET-1 has been identified as one of the most potent and long-lasting vasoconstrictor polypeptides, and it has also been reported to promote cellular proliferation, which may result in vascular smooth muscle hypertrophy (12). Previous studies have reported the potential of the ET-1 gene as a candidate gene to predict the risk of hypertension, whereas ET-1 polymorphisms have been associated with various hypertension risk factors, such as left ventricular hypertrophy and fibrosis, and renal insufficiency (13-15). Therefore, plasma ET-1 levels may be used as an indicator of the severity of hypertension and of hypertension-associated damage of related organs (14). Furthermore, ET-1 has previously been reported to promote the synthesis and release of NO, which has vasodilatory actions (16), whereas their interaction maintains the vascular tension under physiological conditions. NOS is the enzyme responsible for catalyzing the biosynthesis of NO (17). In hypertensive vascular endothelium, the activity of NOS is decreased, due to the insufficient response of the vasculature to endothelium-dependent dilators (17). Three NOS isoforms, nNOS, eNOS and iNOS, are expressed in different cell and tissue types and under different conditions (18). Under physiological conditions, iNOS is not expressed in endothelial cells, whereas eNOS and nNOS constantly synthesize small amounts of NO to maintain the vascular tone $(19,20)$. However, under pathological conditions, endotoxins and various cytokines can induce the expression of iNOS in macrophages and leukocytes, leading to increased NO production, which can exert potent vasodilatory effects (21). NO synthesized by eNOS has been reported to cause smooth muscle relaxation, 
Table IV. Nitric oxide contents in mouse serum, heart, liver, kidney and stomach tissue samples.

\begin{tabular}{lccccc}
\hline Group & Serum $(\mu \mathrm{mol} /$ gprot $)$ & Heart $(\mu \mathrm{mol} /$ gprot $)$ & Liver $(\mu \mathrm{mol} /$ gprot $)$ & Kidney $(\mu$ mol/gprot $)$ & Stomach $(\mu$ mol/gprot $)$ \\
\hline Normal & $65.71 \pm 4.08^{\mathrm{a}}$ & $8.08 \pm 0.71^{\mathrm{a}}$ & $2.68 \pm 0.15^{\mathrm{a}}$ & $7.67 \pm 0.75^{\mathrm{a}}$ & $9.42 \pm 0.41^{\mathrm{a}}$ \\
Control & $32.10 \pm 2.78^{\mathrm{d}}$ & $3.11 \pm 0.42^{\mathrm{d}}$ & $0.50 \pm 0.05^{\mathrm{d}}$ & $4.03 \pm 0.39^{\mathrm{d}}$ & $5.39 \pm 0.26^{\mathrm{d}}$ \\
CJGJ & $44.63 \pm 2.77^{\mathrm{c}}$ & $5.42 \pm 0.41^{\mathrm{c}}$ & $1.39 \pm 0.24^{\mathrm{c}}$ & $5.01 \pm 0.44^{\mathrm{c}}$ & $6.71 \pm 0.52^{\mathrm{c}}$ \\
HLGJ & $52.61 \pm 2.82^{\mathrm{b}}$ & $6.39 \pm 0.32^{\mathrm{b}}$ & $2.11 \pm 0.18^{\mathrm{b}}$ & $6.18 \pm 0.46^{\mathrm{b}}$ & $8.10 \pm 0.43^{\mathrm{b}}$ \\
\hline
\end{tabular}

${ }^{\mathrm{a}-\mathrm{d}}$ Mean values with different letters in the same column are significantly different, $\mathrm{P}<0.05$. Values are expressed as the mean \pm standard deviation. CJGJ, Jiangjin County Gardenia jasminoides variety; HLGJ, Lichuan City Gardenia jasminoides variety; L-NNA, L-N ${ }^{\mathrm{G}}$-nitroarginine.

Table V. Malondialdehyde contents in mouse serum, heart, liver, kidney and stomach tissue samples.

\begin{tabular}{lccccc}
\hline Group & Serum $(\mu \mathrm{mol} /$ gprot $)$ & Heart $(\mu \mathrm{mol} /$ gprot $)$ & Liver $(\mu$ mol/gprot $)$ & Kidney $(\mu$ mol/gprot $)$ & Stomach $(\mu$ mol/gprot $)$ \\
\hline Normal & $4.35 \pm 0.28^{\mathrm{d}}$ & $2.12 \pm 0.20^{\mathrm{d}}$ & $0.42 \pm 0.07^{\mathrm{d}}$ & $1.28 \pm 0.08^{\mathrm{d}}$ & $1.35 \pm 0.12^{\mathrm{d}}$ \\
Control & $11.78 \pm 0.88^{\mathrm{a}}$ & $4.63 \pm 0.28^{\mathrm{a}}$ & $1.08 \pm 0.06^{\mathrm{a}}$ & $2.97 \pm 0.19^{\mathrm{a}}$ & $3.87 \pm 0.11^{\mathrm{a}}$ \\
CJGJ & $8.36 \pm 0.42^{\mathrm{b}}$ & $3.41 \pm 0.22^{\mathrm{b}}$ & $0.79 \pm 0.05^{\mathrm{b}}$ & $2.09 \pm 0.16^{\mathrm{b}}$ & $2.59 \pm 0.17^{\mathrm{b}}$ \\
HLGJ & $6.97 \pm 0.27^{\mathrm{c}}$ & $2.81 \pm 0.19^{\mathrm{c}}$ & $0.65 \pm 0.04^{\mathrm{c}}$ & $1.72 \pm 0.18^{\mathrm{c}}$ & $1.92 \pm 0.15^{\mathrm{c}}$
\end{tabular}

${ }^{\mathrm{a}-\mathrm{d}}$ Mean values with different letters in the same column are significantly different, $\mathrm{P}<0.05$. Values are expressed as the mean \pm standard deviation. CJGJ, Jiangjin County Gardenia jasminoides variety; HLGJ, Lichuan City Gardenia jasminoides variety; L-NNA, L-NG-nitroarginine.

Table VI. Serum levels of ET-1, CGRP and VEGF in mice.

\begin{tabular}{lrrrr}
\hline Group & ET-1 $(\mathrm{pg} / \mathrm{ml})$ & CGRP $(\mathrm{pg} / \mathrm{ml})$ & VEGF $(\mathrm{pg} / \mathrm{ml})$ & E-selectin $(\mathrm{ng} / \mathrm{ml})$ \\
\hline Normal & $73.87 \pm 3.82^{\mathrm{d}}$ & $180.68 \pm 5.03^{\mathrm{a}}$ & $119.75 \pm 4.98^{\mathrm{d}}$ & $445.63 \pm 17.42^{\mathrm{d}}$ \\
Control & $126.54 \pm 6.74^{\mathrm{a}}$ & $64.78 \pm 3.25^{\mathrm{d}}$ & $292.63 \pm 7.85^{\mathrm{a}}$ & $735.95 \pm 28.43^{\mathrm{a}}$ \\
CJGJ & $95.62 \pm 3.55^{\mathrm{b}}$ & $116.97 \pm 4.58^{\mathrm{c}}$ & $208.71 \pm 6.31^{\mathrm{b}}$ & $608.34 \pm 20.64^{\mathrm{b}}$ \\
HLGJ & $83.47 \pm 3.08^{\mathrm{c}}$ & $135.20 \pm 4.03^{\mathrm{b}}$ & $177.98 \pm 7.81^{\mathrm{c}}$ & $541.36 \pm 16.50^{\mathrm{c}}$
\end{tabular}

${ }^{\mathrm{a}-\mathrm{d} M e a n}$ values with different letters in the same column are significantly different, $\mathrm{P}<0.05$. Values are expressed as the mean \pm standard deviation. CJGJ, Jiangjin County Gardenia jasminoides variety; HLGJ, Lichuan City Gardenia jasminoides variety; ET, endothelin; CGRP, calcitonin gene-related peptide; VEGF, vascular endothelial growth factor; L-NNA, L-NG-nitroarginine.

inhibit vascular smooth muscle cellular proliferation, inhibit platelet aggregation, and maintain normal vascular tension and arterial blood pressure (22). However, previous studies have suggested that under pathological conditions, such as hypertension and atherosclerosis, eNOS-produced NO may be insufficient to maintain normal vascular tension, resulting in iNOS activation and increased NO production, in an effort to maintain physiological blood pressure levels $(22,23)$.

E-selectin is a cell adhesion molecule specifically expressed on cytokine-activated endothelial cells; therefore, soluble E-selectin in peripheral blood can be used as a specific marker of endothelial cell activation (24). Serum levels of soluble E-selectin have been reported to be significantly increased in hypertensive patients, thus suggesting that vascular endothelial cells may be activated by high blood pressure (25). In addition, E-selectin has been reported to mediate leukocyte adhesion, which may damage vascular endothelial cells and cause their degeneration, necrosis and apoptosis, thus leading to atherosclerotic lesion formation, as well as lumen deformation and stenosis (26).
CGRP has been identified as one of the most potent vasodilatory neuropeptides. It has previously been reported that CGRP plasma levels in patients with essential hypertension were significantly lower compared with in healthy subjects, thus suggesting a role for CGRP in the pathogenesis of hypertension (27). CGRP has been reported to promote NOS activity and NO production in vascular smooth muscle cells, and NO may participate in its vasodilatory mechanism. Inadequate plasma CGRP secretion in patients with essential hypertension may lead to reduced NOS activity and NO levels, thus resulting in increased blood pressure (28). ADM has been identified in plasma and several tissues, whereas vascular endothelial cells have been reported as the main source of plasma ADM. ADM is a member of the CGRP superfamily and shares high sequence homology with CGRP, thus suggesting that ADM may exert its actions via binding to CGRP receptors in endothelial cells. In addition, ADM may participate in the regulation of vasoactive substance levels, which serve critical roles in the maintenance of vascular tension (29). Furthermore, ADM has been 

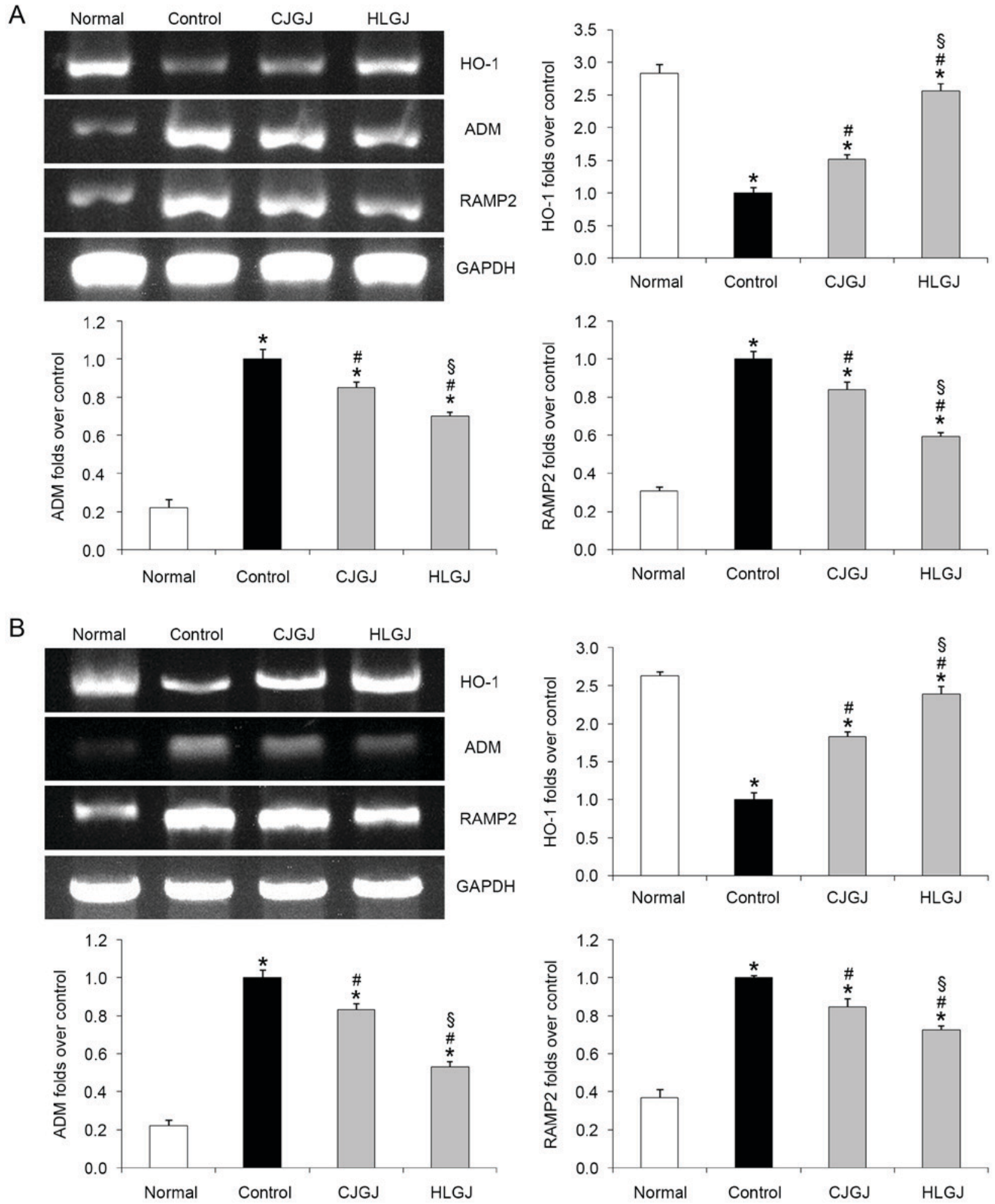

Figure 2. Effects of treatment with Gardenia jasminoides on mRNA expression levels of HO-1, ADM and RAMP2 in (A) mouse myocardial tissue samples and (B) in mouse blood vessel tissue samples. Data are expressed as the mean \pm standard deviation of 3 independent experiments. *P<0.05 vs. normal group; ${ }^{\#} \mathrm{P}<0.05$ vs. control group; ${ }^{\S} \mathrm{P}<0.05$ vs. CJGJ group. HO, heme oxygenase; ADM, adrenomedullin; RAMP, receptor activity modifying protein; L-NNA, L-N ${ }^{\mathrm{G}}$-nitroarginine; CJGJ, Jiangjin County Gardenia jasminoides variety; HLGJ, Lichuan City Gardenia jasminoides variety.

demonstrated to inhibit the release of ET-1 and angiotensin (Ang), and to suppress their vasoconstrictive actions (30). Sumimoto et al (31) reported that plasma ADM levels in hypertensive patients were markedly increased compared with in healthy subjects. It has previously been revealed that following myocardial infarction and heart failure in mice, ADM and
RAMP2 mRNA expression levels were increased in ischemic, as well as in non-infarcted myocardial tissue (32). Under pathological conditions, such as shock, congestive heart failure and obstructive nephropathy, ADM and RAMP2 expression in cardiovascular tissue may be altered as a result of compensatory mechanisms aiming to protect cardiovascular function (33). 

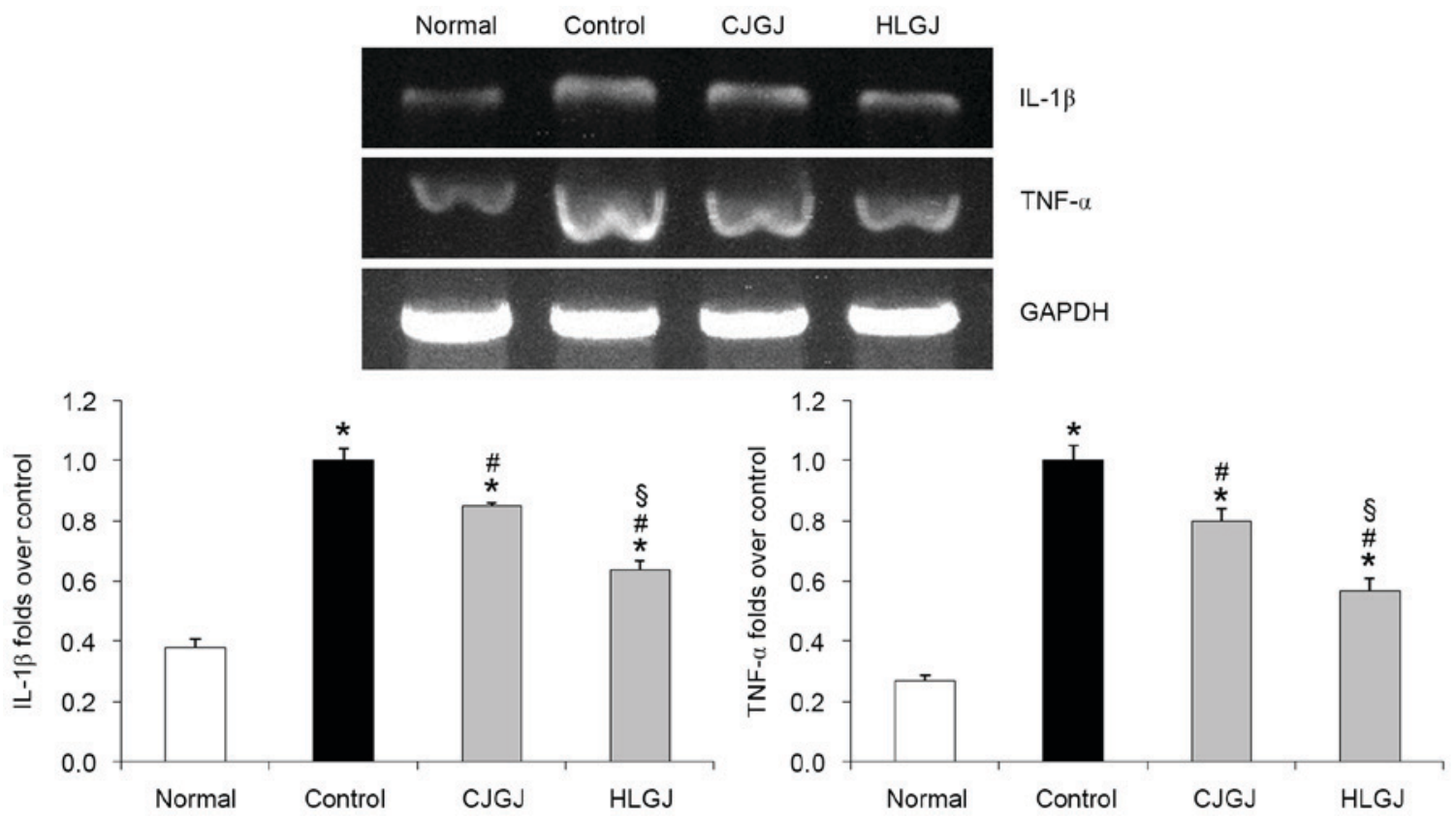

Figure 3. Effects of treatment with Gardenia jasminoides on mRNA expression levels of IL-1 $\beta$ and TNF- $\alpha$ in mouse blood vessel tissue samples. Normal mice were treated with saline. Control mice were treated with L-NNA. Mice in the CJGJ group were treated with L-NNA and CJGJ. Mice in the HLGJ group were treated with L-NNA and HLGJ. Data are expressed as the mean \pm standard deviation of 3 independent experiments. "P<0.05 vs. normal group; ${ }^{\#} \mathrm{P}<0.05$ vs. control group; ${ }^{\circledR} \mathrm{P}<0.05$ vs. CJGJ group. IL, interleukin; TNF, tumor necrosis factor; L-NNA, L-N ${ }^{\mathrm{G}}$-nitroarginine; CJGJ, Jiangjin County Gardenia jasminoides variety; HLGJ, Lichuan City Gardenia jasminoides variety.

In accordance with a previous study (34), the present results demonstrated that ADM and RAMP2 mRNA expression levels were increased in myocardial and blood vessel tissue isolated from hypertensive mice compared with in normal mice.

Following hypertension-induced cerebral tissue damage, immune cells, astrocytes, endothelial cells and neurons have been reported to express TNF- $\alpha$ and other pro-inflammatory cytokines, such as IL-6 (35). IL-6 has been reported to induce fibrinogen activation and blood clot formation, leading to fibroblast hyperplasia and collagen deposition in inflamed vasculature. In addition, IL-6 is able to promote the activation and aggregation of platelets, thus leading to endothelial cell damage (36). Ang II has also been revealed to stimulate vascular smooth muscle cells to increase the synthesis and release of IL-6, andIL-6 upregulates Ang II receptors. Furthermore, during the pathogenesis of essential hypertension, Ang II has been demonstrated to increase peripheral resistance via smooth muscle contraction, and thus increase blood pressure (37).

VEGF is a glycosylated secretory peptide factor, and the important pro-angiogenic protein, which selectively stimulates mitosis and proliferation of endothelial cells, promotes angiogenesis and increases vascular permeability (38). Hypertensive patients have been reported to exhibit increased serum VEGF levels compared with healthy subjects. The reduced blood flow leading to partial ischemia hypoxia and increased cytokine levels in tissues of hypertensive patients may underlie the increased serum levels of VEGF observed in these patients (39).

Oxidative stress has been associated with hypertension and reactive oxygen species have been suggested to be implicated in its pathogenesis (40). It has previously been demonstrated that damage induced by free radicals participates in the development of hypertension (41). MDA is a product of unsaturated fatty acid decomposition, which can be used as a biomarker to reflect the production of oxygen free radicals. Research has demonstrated that patients with hypertension and ischemic stroke may exhibit higher MDA compared with controls (42).

The HO enzymatic system has been reported to exert cytoprotective effects against oxidative damage. $\mathrm{HO}$ is the key enzyme involved in heme degradation, and catalyzes the catabolism of heme to produce the antioxidant molecule bilirubin, the vasodilatory gas carbon monoxide and $\mathrm{Fe}^{2+}(43)$. Under physiological or pathological conditions, the induction of HO-1 activity has been demonstrated to protect against oxidative damage; HO-1-associated cytoprotection has been attributed to the antioxidant properties of bilirubin (44). In addition, HO-1 has been reported to exert protective effects on cardiovascular function, as, through its antioxidant action, it protects vascular endothelial cells and cardiomyocytes from oxidative damage (45). HO-1 also directly inhibits cardiomyocyte hypertrophy and reduces the left/right ventricle weight ratio. Furthermore, $\mathrm{HO}-1$ was previously demonstrated to exert anti-hypertensive effects, which were associated with improved endothelial function (46).

Previous studies have reported that crocin prevented endothelial cell injury, and thus counteracted the development of hypertension and atherosclerosis, as well as cerebral edema, spinal cord injury, papilloma and arthritis; crocin-1 appeared to exert stronger effects $(47,48)$. Genipin 1-gentiobioside has been reported to exhibit protective properties against heart failure (49). Furthermore, it has previously been reported that gardenoside protected vascular endothelial cells against oxidative damage and prevented the development of hypertension (50).

Bax and Bcl-2 are apoptosis-associated genes. Previous studies have demonstrated that in hypertensive mice with 

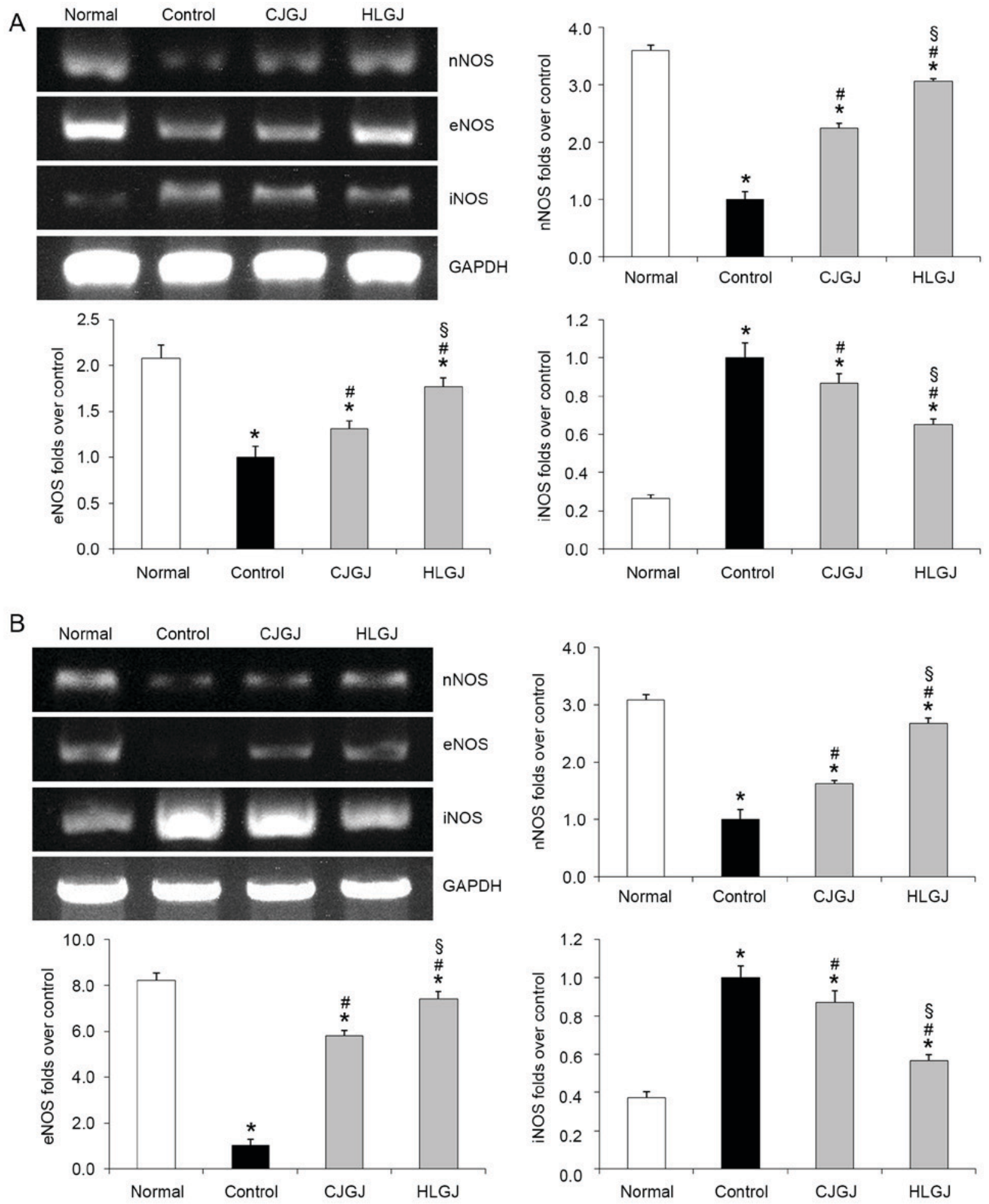

Figure 4. Effects of treatment with Gardenia jasminoides on mRNA expression levels of nNOS, eNOS and iNOS in (A) mouse myocardial tissue samples and (B) blood vessel tissue samples. Normal mice were treated with saline. Control mice were treated with L-NNA. Mice in the CJGJ group were treated with L-NNA and CJGJ. Mice in the HLGJ group were treated with L-NNA and HLGJ. Data are expressed as the mean \pm standard deviation of 3 independent experiments. " $\mathrm{P}<0.05$ vs. the normal group; ${ }^{\#} \mathrm{P}<0.05$ vs. control group; ${ }^{\circledR} \mathrm{P}<0.05$ vs. CJGJ group. $\mathrm{n}$, neuronal; NOS, nitric oxide synthase; e, endothelial; i, inducible; L-NNA, L-N ${ }^{\mathrm{G}}$-nitroarginine; CJGJ, Jiangjin County Gardenia jasminoides variety; HLGJ, Lichuan City Gardenia jasminoides variety.

left ventricular hypertrophy, myocardial cell apoptosis was enhanced, and the expression of Bax was upregulated, whereas the expression of Bcl-2 was downregulated (51-53). Therefore, to successfully treat hypertension, myocardial cell apoptosis, myocardial hypertrophy and the development of heart failure should be addressed (54). The cardiovascular actions of Ang II have been reported to be primarily mediated by type 1 Ang II receptors. Ang II receptor activation stimulated the expression of Bax, inhibited the expression of Bcl-2 and increased the phosphorylation of target proteins, which eventually led 

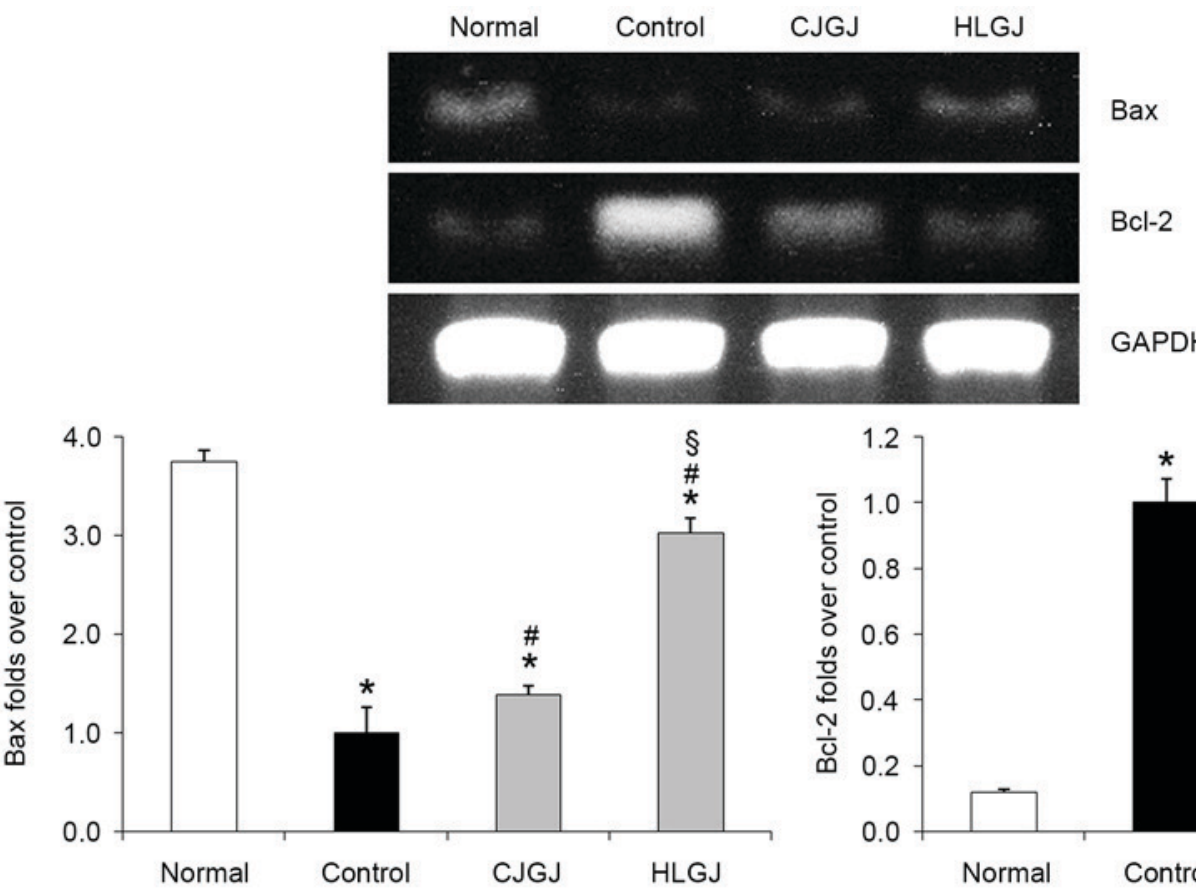

GAPDH

Figure 5. Effects of treatment with Gardenia jasminoides on mRNA expression levels of Bcl-2 and Bax in mouse myocardial tissue samples. Normal mice were treated with saline. Control mice were treated with L-NNA. Mice in the CJGJ group were treated with L-NNA and CJGJ. Mice in the HLGJ group were treated with L-NNA and HLGJ. Data are expressed as the mean \pm standard deviation of 3 independent experiments. "P $<0.05$ vs. normal group; ${ }^{\text {P }}<0.05$ vs. control group; ${ }^{\circledR} \mathrm{P}<0.05$ vs. CJGJ group. Bcl-2, B-cell lymphoma-2; Bax, Bcl-2-associated X protein; L-NNA, L-N ${ }^{\mathrm{G}}$-nitroarginine; CJGJ, Jiangjin County Gardenia jasminoides variety; HLGJ, Lichuan City Gardenia jasminoides variety.
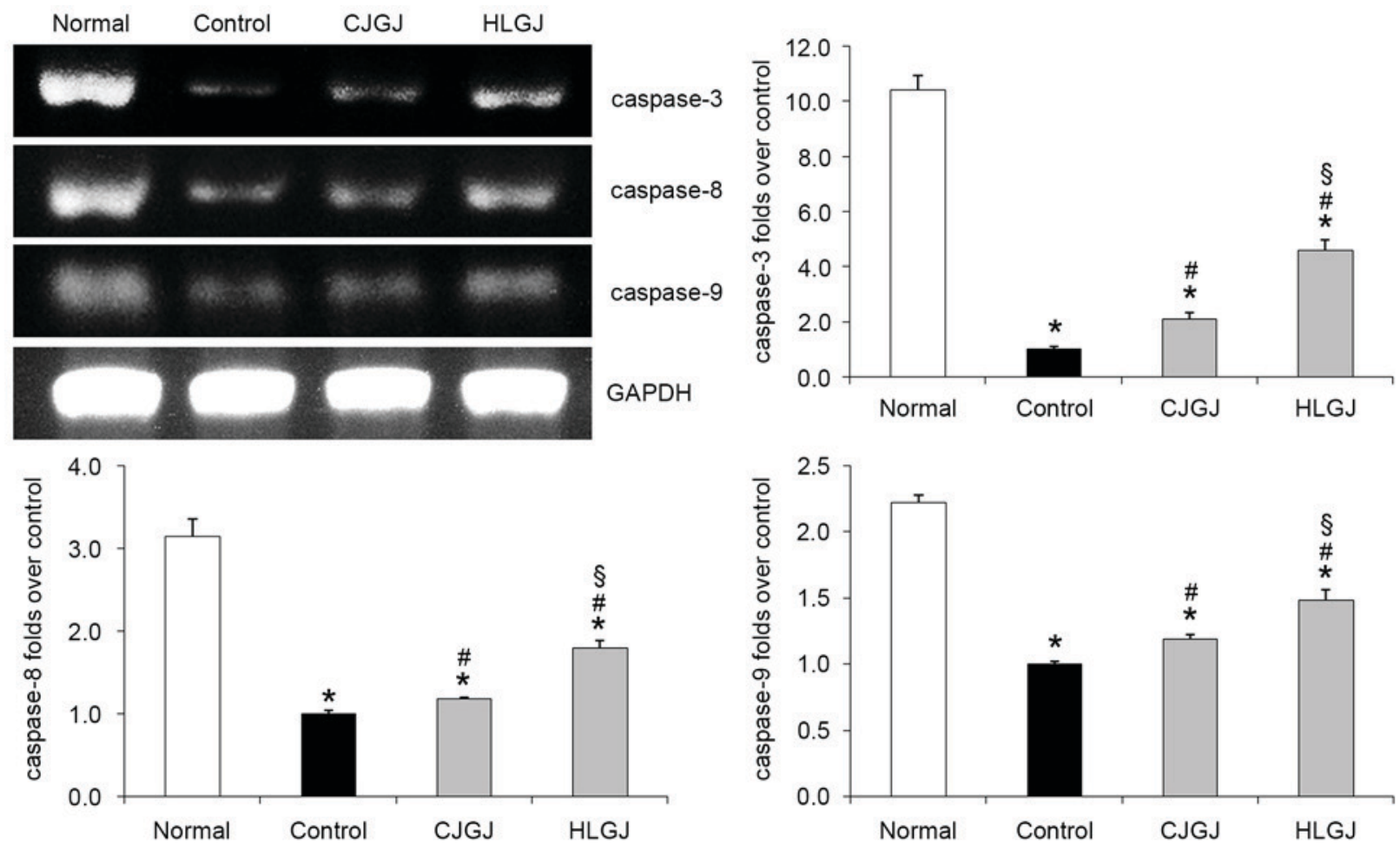

Figure 6. Effects of treatment with Gardenia jasminoides on mRNA expression levels of caspase-3, caspase-8 and caspase-9 in mouse myocardial tissue samples. Normal mice were treated with saline. Control mice were treated with L-NNA. Mice in the CJGJ group were treated with L-NNA and CJGJ. Mice in the HLGJ group were treated with L-NNA and HLGJ. Data are expressed as the mean \pm standard deviation of 3 independent experiments. "P $<0.05$ vs. the normal group; "P<0.05 vs. the control group; ${ }^{\circledR} \mathrm{P}<0.05$ vs. the CJGJ group. L-NNA, L-N ${ }^{\mathrm{G}}$-nitroarginine; CJGJ, Jiangjin County Gardenia jasminoides variety; HLGJ, Lichuan City Gardenia jasminoides variety.

to caspase activation and the induction of apoptosis (55). Ang II induced myocardial cell apoptosis and increased blood pressure, and caspase- 3 reduced the effects of Ang II and reduced blood pressure (56). 
A
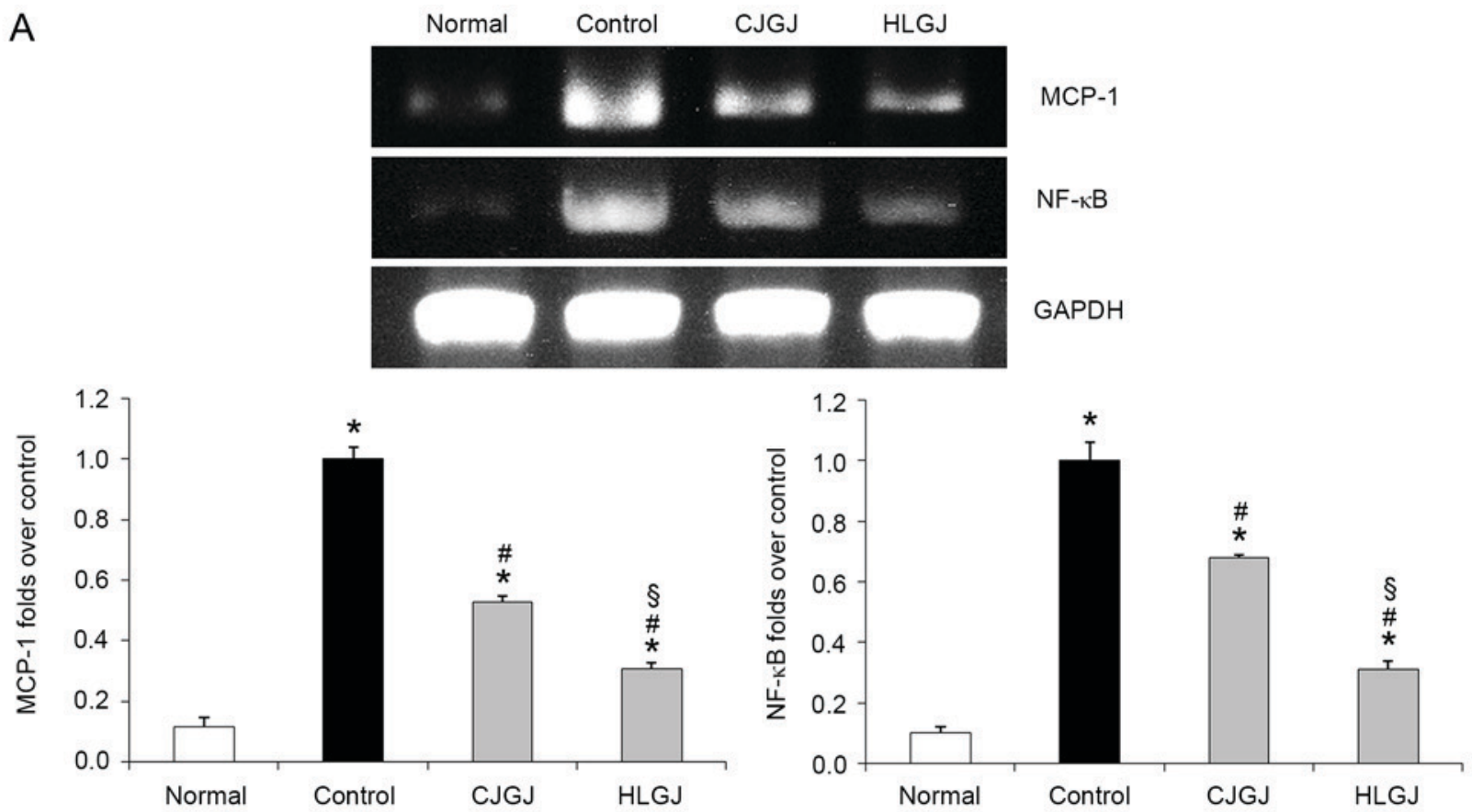

B
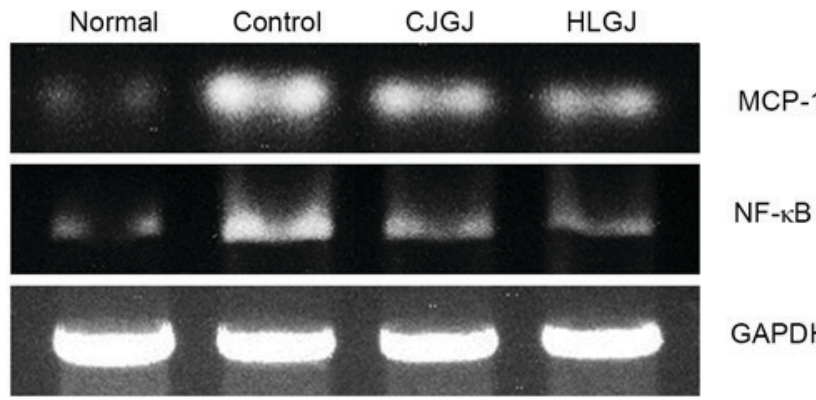

NF-KB

GAPDH
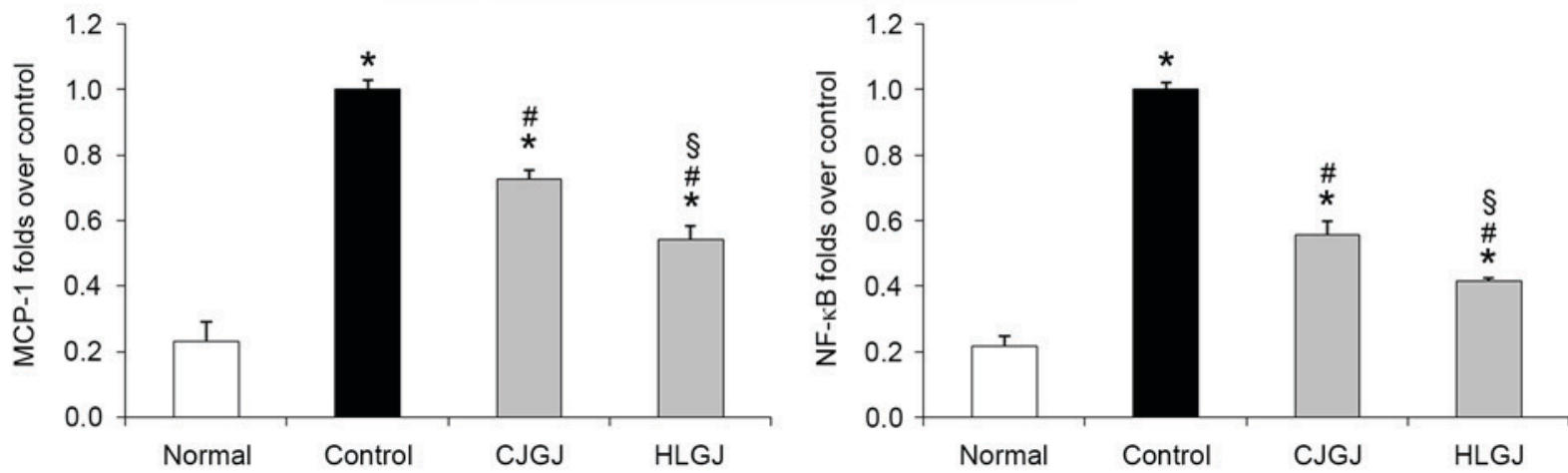

Figure 7. Effects of treatment with Gardenia jasminoides on mRNA expression levels of MCP-1 and NF-kB in (A) mouse myocardial tissue samples and (B) mouse blood vessel tissue samples. Normal mice were treated with saline. Control mice were treated with L-NNA. Mice in the CJGJ group were treated with L-NNA and CJGJ. Mice in the HLGJ group were treated with L-NNA and HLGJ. Data are expressed as the mean \pm standard deviation of 3 independent experiments. ${ }^{*} \mathrm{P}<0.05$ vs. the normal group; ${ }^{\prime} \mathrm{P}<0.05$ vs. the control group; ${ }^{\circledR} \mathrm{P}<0.05$ vs. the CJGJ group. MCP, monocyte chemoattractant protein; $\mathrm{NF}$, nuclear factor; L-NNA, L-N ${ }^{\mathrm{G}}$-nitroarginine; CJGJ, Jiangjin County Gardenia jasminoides variety; HLGJ, Lichuan City Gardenia jasminoides variety.

The development of hypertension and hypertension-induced organ damage, as well as the progression of atherosclerosis, are associated with vascular inflammation. Hypertensive patients exhibit increased levels of pro-inflammatory cytokines, including TNF- $\alpha$, IL-1 $\beta$ and MCP-1, compared with normotensive subjects. The inhibition of pro-inflammatory factors has been demonstrated to reduce MCP-1 expression and inhibit the activation of NF- $\mathrm{KB}$ (57).
Inhibiting Ang II led to a series of effects on inflammation, including reduced levels of macrophages and T lymphocytes, which subsequently led to reduced blood pressure (58).

MMPs are a family of $\mathrm{Zn}^{2+}$-containing proteases, that are responsible for the degradation of extracellular matrix components; therefore, they are critical in tissue remodeling (59). High blood pressure has been reported to cause left ventricular remodeling, which has been identified as a risk factor for heart 
A

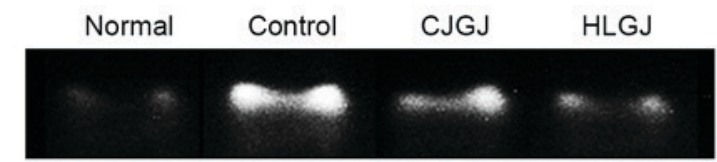

MMP-2

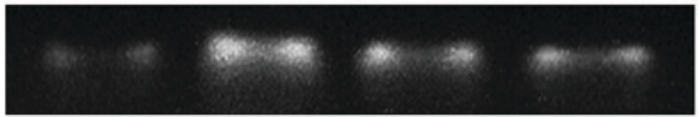

MMP-9

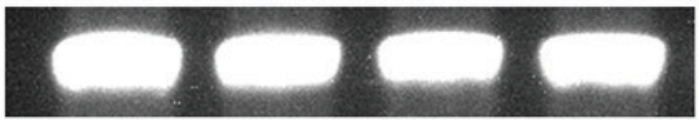

GAPDH
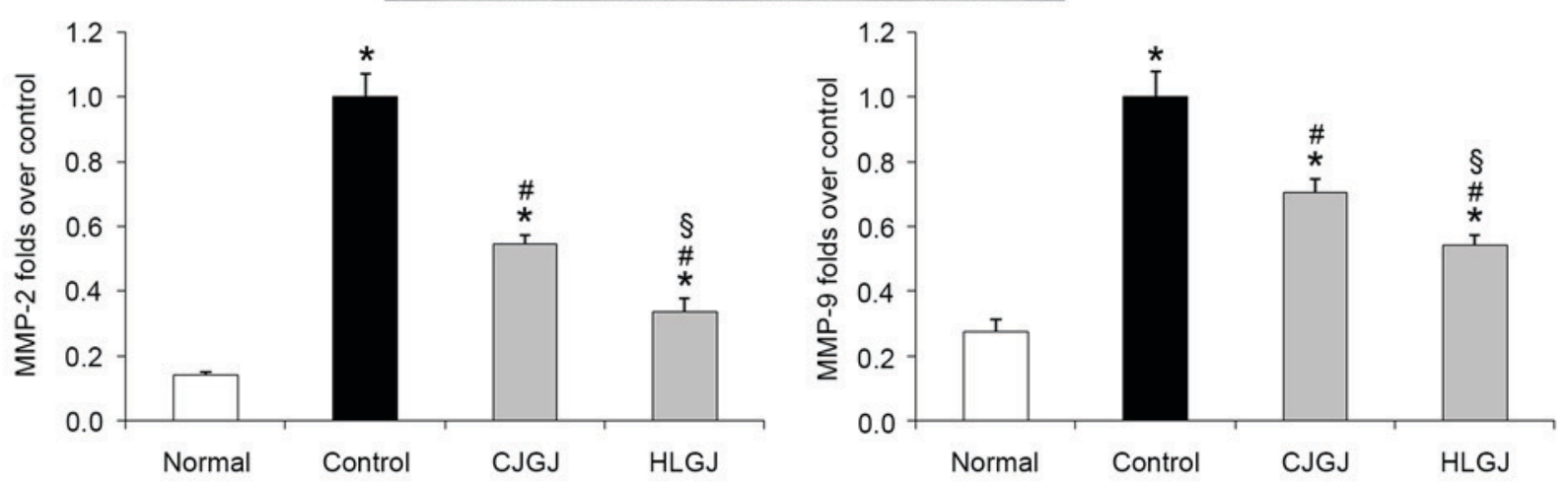

B

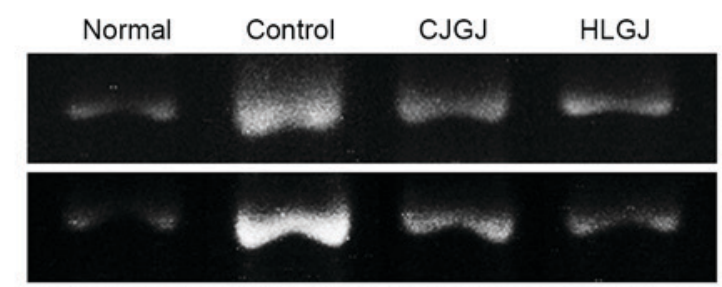

MMP-2

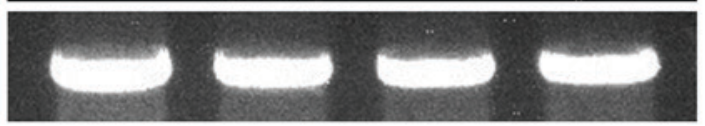

GAPDH
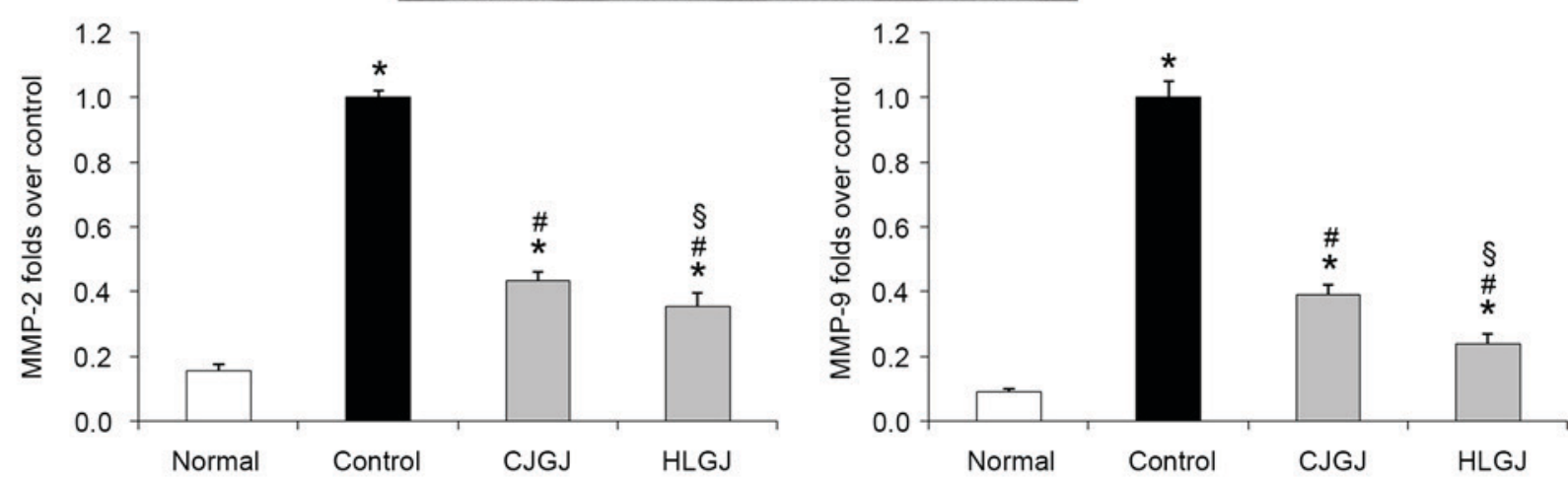

Figure 8. Effects of treatment with Gardenia jasminoides on mRNA expression levels of MMP-2 and MMP-9 in (A) mouse myocardial tissue samples and (B) mouse blood vessel tissue samples. Normal mice were treated with saline. Control mice were treated with L-NNA. Mice in the CJGJ group were treated with L-NNA and CJGJ. Mice in the HLGJ group were treated with L-NNA and HLGJ. Data are expressed as the mean \pm standard deviation of 3 independent experiments. ${ }^{*} \mathrm{P}<0.05$ vs. the normal group; ${ }^{\mathrm{P}}<0.05$ vs. the control group; ${ }^{\circledR} \mathrm{P}<0.05$ vs. the CJGJ group. MMP, matrix metalloproteinase; L-NNA, L-N $\mathrm{N}^{\mathrm{G}}$-nitroarginine; CJGJ, Jiangjin County Gardenia jasminoides variety; HLGJ, Lichuan City Gardenia jasminoides variety.

failure and other cardiovascular events (60). Previous studies using mouse models of hypertension and heart failure have demonstrated that the activity of MMP-2 and MMP-9 was significantly enhanced in myocardial tissue. These results suggested that MMP-2 and MMP-9 may serve important roles in ventricular remodeling processes induced by hypertension $(61,62)$.

The present study demonstrated that crocin- 1 and crocin- 2 contents were similar in CJGJ and HLGJ Gardenia jasminoides varieties. CJGJ appeared to be enriched in genipin 1-gentiobioside compared with HLGJ. Conversely, HLGJ exhibited higher gardenoside contents compared with CJGJ. Notably, HLGJ appeared to exert more potent anti-hypertensive effects compared with CJGJ in the L-NNA-induced mouse model of hypertension. Therefore, it may be hypothesized that the higher gardenoside contents of HLGJ are critical for its anti-hypertensive effects. These results were similar to previous research where gardenoside was demonstrated to reduce 
blood pressure (50). In addition, treatment of L-NNA-induced hypertensive mice with Gardenia jasminoides increased their NO, CGRP, HO-1, nNOS, eNOS, Bax, caspase-3, caspase-8 and caspase-9 levels, and reduced their MDA, ET-1, VEGF, E-selectin, ADM, RAMP2, IL-1 $\beta$, TNF- $\alpha$, iNOS, Bcl-2, MCP-1, NF-кB, MMP-2 and MMP-9 levels. Previous studies demonstrated that changes in the expression of these genes were associated with changes in blood pressure (63-65), which was confirmed by the results of the present study. These results may demonstrate the mechanism of action of Gardenia jasminoides, and may guide the development of treatments based on the structure of Gardenia jasminoides. Further experiments involving chemical structure analysis and application to clinical experiments are required prior to the development and application of Gardenia jasminoides-based treatments.

\section{Acknowledgements}

The present study was supported by the Science and Technology Innovation Action Plan of Shanghai (grant no. 14495800400), the Basic Research Project of Chongqing Frontier and Application (grant no. cstc2014jcyjA1466), the Construction Program of Chongqing Engineering Research Center (grant no. cstc2015yfpt_gcjsyjzx0027) and the Program for Innovation Team Building at Institutions of Higher Education in Chongqing (grant no. CXTDX201601040).

\section{References}

1. GuWL, Shi ZX, Yu YX, Wu YW, Lu BW and Hui KK Distribution characteristics of syndrome types in essential hypertension. Zhong Xi Yi Jie He Xue Bao 8: 842-847, 2010 (In Chinese)

2. Xu HY and Wang YQ: Investigation and application for the therapy of hypertension with traditional Chinese medicine China Prac Med 3: 189-192, 2008 (In Chinese).

3. Shen CZ, Peng MC, Kuang HR and Cheng ZQ: The effect of Chinese food therapy on the quality of life in patients with hypertension. Chin J Nurs 44: 510-513, 2009 (In Chinese).

4. Jiang CX, Cheng JG and Luo T: Nutritional value analysis of medicinal and edible plant. J Anhui Agri Sci 43: 282-284, 2015.

5. Meng XL, Li HW, Li Y, Yu Q, Wan LL and Guo C: Advances in Studies on chemical constituents and pharmacological activities of Gardenia jasminoides. Chinese J New Drug 20: 959-967, 2011.

6. Chen H, Xiao YQ, Li L and Zhang C: Studies on chemical constituents in fruit of Gardenia jasminoides. Zhongguo Zhong Yao Za Zhi 32: 1041-1043, 2007 (In Chinese).

7. Chen SC, Shi HY, Yang N and Wang R: Comparison of main effective constituent content of Gardenia jasminoides in Chongqing Hou-shan and other domestic areas. China J Exp Tradit Med Formulae 18: 131-134, 2012 (In Chinese).

8. Thomsen K, Rubin I and Lauritzen M: NO- and non-NO-, non-prostanoid-dependent vasodilatation in rat sciatic nerve during maturation and developing experimental diabetic neuropathy. J Physiol 543: 977-993, 2002.

9. Gangula P, Ravella K, Chukkapalli S, Rivera M, Srinivasan S, Hale A, Channon K, Southerland J and Kesavalu L: Polybacterial periodontal pathogens alter vascular and gut BH4/nNOS/NRF2-phase II enzyme expression. PLoS One 10: e0129885, 2015

10. Simmonds MJ, Detterich JA and Connes P: Nitric oxide, vasodilation and the red blood cell. Biorheology 51: 121-134, 2014.

11. Zhao X, Wang Q, Li J, Chen F, Qian Y and Wang R: In vitro antioxidant, anti-mutagenic, anti-cancer and anti-angiogenic effects of Chinese Bowl tea. J Funct Food 7: 590-598, 2014.

12. Silva I, Teixeira A, Oliveira J, Almeida I, Almeida R and Vasconcelos C: Predictive value of vascular disease biomarkers for digital ulcers in systemic sclerosis patients. Clin Exp Rheumatol 33 (4 Suppl 91): S127-S130, 2015.
13. Gu X, Li H, Zhu X, Gu H, Chen J, Wang L, Harding P and Xu W: Inverse correlation between plasma adropin and ET-1 levels in essential hypertension: A cross-sectional study. Medicine (Baltimore) 94: e1712, 2015.

14. Li X, Qiu J, Pan M, Zheng D, Su Y, Wei M, Kong X, Sun W and Zhu J: Correlation between congenital heart disease complicated with pulmonary artery hypertension and circulating endothelial cells as well as endothelin-1. Int J Clin Exp Pathol 8: 10743-10751, 2015.

15. Renga B, Cipriani S, Carino A, Simonetti M, Zampella A and Fiorucci S: Reversal of endothelial dysfunction by GPBAR1 agonism in portal hypertension involves a AKT/FOXOA1 dependent regulation of $\mathrm{H} 2 \mathrm{~S}$ generation and endothelin-1. PLoS One 10: e0141082, 2015.

16. Feng EZ, Yang SY, Huang NX, Yin H, Zhang Y and Tian ZX: Plasma endothelin-1 and nitric oxide correlate with ligustrazine alleviation of pulmonary artery hypertension in patients of chronic corpulmonale from high altitude plateau during acute exacerbation.Zhongguo Ying Yong Sheng Li Xue Za Zhi 30: 532-527, 2014.

17. Basralı F, Nasırcılar Ülker S, Koçer G, Ülker Karadamar P, Özyurt D, Cengiz M and Şentürk ÜK: Effect of magnesium on vascular reactivity in NOS inhibition-induced hypertension. Magnes Res 28: 64-74, 2015.

18. Nieto CI, Cabildo MP, Cornago MP, Sanz D, Claramunt RM, Torralba MC, Torres MR, Elguero J, García JA, López A, et al: Fluorination effects on NOS inhibitory activity of pyrazoles related to curcumin. Molecules 20: 15643-15665, 2015.

19. Kubes P and McCafferty DM: Nitric oxide and intestinal inflammation. Am J Med 109: 150-158, 2000

20. Posa A,Pavo N,Hemetsberger R, CsonkaC, Csont T,Ferdinandy P, Petrási Z, Varga C, Pavo IJ, Laszlo F Jr, et al: Protective effect of ischaemic preconditioning on ischaemia/reperfusion-induced microvascular obstruction determined by on-line measurements of coronary pressure and blood flow in pigs. Thromb Haemost 103: 450-460, 2010.

21. Huang HC, Wang SS, Chang CC, Lee FY, Lin HC, Hou MC, Teng TH, Chen YC and Lee SD: Evolution of portal-systemic collateral vasopressin response in endotoxemic portal hypertensive rats. Shock 32: 503-508, 2009.

22. Pulgar VM, Yamaleyeva LM, Varagic J, McGee C, Bader M, Dechend R and Brosnihan KB: Functional changes in the uterine artery precede the hypertensive phenotype in a transgenic model of hypertensive pregnancy. Am J Physiol Endocrinol Metab 309: E811-E817, 2015.

23. Theodorakis NG, Wang YN, Korshunov VA, Maluccio MA and Skill NJ: Thalidomide ameliorates portal hypertension via nitric oxide synthase independent reduced systolic blood pressure. World J Gastroenterol 21: 4126-4135, 2015.

24. Le Hiress M, Tu L, Ricard N, Phan C, Thuillet R, Fadel E, Dorfmüller P, Montani D, de Man F, Humbert M, et al: Proinflammatory signature of the dysfunctional endothelium in pulmonary hypertension. role of the macrophage migration inhibitory factor/CD74 complex. Am J Respir Crit Care Med 192: 983-997, 2015.

25. Zhang JL, Qin YW, Zheng X, Qiu JL, Zhang LZ, Zhang JR and Bian JL: Relevance of serum soluble E-selectin level and blood pressure in hypertensive patients. Shanghai Med J 27: 7-9, 2004.

26. Chen J and Li J: Clinical curative effect and influence on E-selectin, iNOS, eNOS in patient of essential hypertension with massotherapy. China J Tradit Chinese Med Pharm 25: 1708-1710, 2010.

27. Calò LA, Dal Maso L, Pagnin E, Ravarotto V, Facco M, Boscaro E, Maiolino G, Pessina AC and Rossi GP: Effect of olmesartan medoxomil on number and survival of circulating endothelial progenitor cells and calcitonin gene related peptide in hypertensive patients. J Hypertens 32: 193-199, 2014.

28. Wang ZG, Liu JL, Liu Y, Wen SJ, Wen J, Liu YP, Chen XJ and Wu ZS: Increased plasma vasoactive substances and antioxidant enzymes levels in prehypertensive patients. Zhonghua Xin Xue Guan Bing Za Zhi 35: 719-722, 2007 (In Chinese).

29. Nakamura M, Han B, Nunobiki O and Kakudo K: Adrenomedullin: A tumor progression factor via angiogenic control. Curr Cancer Drug Targets 6: 635-643, 2006.

30. Liu K, Deng X, Gong L, Chen X, Wang S, Chen H, Chen X, Amrit B and He S: The effect of intermedin on angiotensin II and endothelin-1 induced ventricular myocyte hypertrophy in neonatal rat. Clin Lab 59: 589-596, 2013.

31. Sumimoto T, Nishikimi T, Mukai M, Matsuzaki K, Murakami E, Takishita S, Miyata A, Matsuo H and Kangawa K: Plasma adrenomedullin concentrations and cardiac and arterial hypertrophy in hypertension. Hypertension 30: 741-745, 1997. 
32. Oie E, Vinge LE, Yndestad A, Sandberg C, Grøgaard HK and Attramadal $\mathrm{H}$ : Induction of a myocardial adrenomedullin signaling system during ischemic heart failure in rats. Circulation 101: 415-422, 2000.

33. Sano M, Kuroi N, Nakayama T, Sato N, Izumi Y, Soma M and Kokubun S: Association study of calcitonin-receptor-like receptor gene in essential hypertension. Am J Hypertens 18: 403-408, 2005.

34. Gong YS, Fan XF, Wu XM, Hu LG, Tang CS, Pang YZ and Qi YF: Changes of intermedin/adrenomedullin 2 and its receptors in the right ventricle of rats with chronic hypoxic pulmonary hypertension. Sheng Li Xue Bao 59: 210-214, 2007 (In Chinese)

35. Jian L, Fa X, Zhou Z and Liu S: Functional analysis of UMOD gene and its effect on inflammatory cytokines in serum of essential hypertension patients. Int J Clin Exp Pathol 8: 11356-11363, 2015.

36. Good RB, Gilbane AJ, Trinder SL, Denton CP, Coghlan G, Abraham DJ and Holmes AM: Endothelial to mesenchymal transition contributes to endothelial dysfunction in pulmonary arterial hypertension. Am J Pathol 185: 1850-1858, 2015.

37. Manhiani MM, Seth DM, Banes-Berceli AK, Satou R, Navar LG and Brands MW: The role of IL-6 in the physiologic versus hypertensive blood pressure actions of angiotensin II. Physiol Rep 3: pii: e12595, 2015.

38. Serban D, Leng J and Cheresh D: H-ras regulates angiogenesis and vascular permeability by activation of distinct downstream effectors. Circ Res 102: 1350-1358, 2008.

39. Muti LA, Pârvu AE, Crăciun AM, Miron N and Acalovschi M: Nitro-oxidative stress, VEGF and MMP-9 in patients with cirrhotic and non-cirrhotic portal hypertension. Clujul Med 88: 140-145, 2015.

40. Minarchick VC, Stapleton PA, Sabolsky EM and Nurkiewicz TR: Cerium dioxide nanoparticle exposure improves microvascular dysfunction and reduces oxidative stress in spontaneously hypertensive rats. Front Physiol 6: 339, 2015.

41. Zhou Y, Zhao L, Zhang Z and Lu X: Protective effect of enalapril against methionine-enriched diet-induced hypertension: Role of endoplasmic reticulum and oxidative stress. Biomed Res Int 2015: 724876, 2015

42. Zhang S, Yang T, Xu X, Wang M, Zhong L, Yang Y, Zhai Z, Xiao $\mathrm{F}$ and Wang C: Oxidative stress and nitric oxide signaling related biomarkers in patients with pulmonary hypertension: A case control study. BMC Pulm Med 15: 50, 2015.

43. Pérez-de-Puig I, Martín A, Gorina R, de la Rosa X, Martinez E and Planas AM: Induction of hemeoxygenase-1 expression after inhibition of hemeoxygenase activity promotes inflammation and worsens ischemic brain damage in mice. Neuroscience 243 22-32, 2013.

44. He M, Nitti M, Piras S, Furfaro A, Traverso N, Pronzato MA and Mann GE: Heme oxygenase-1-derived bilirubin protects endothelial cells against high glucose-induced damage. Free Radic Biol Med 89: 91-98, 2015

45. Chao HM, Chuang MJ, Liu JH, Liu XQ, Ho LK, Pan WH, Zhang XM, Liu CM, Tsai SK, Kong CW, et al: Baicalein protects against retinal ischemia by antioxidation, antiapoptosis, downregulation of HIF-1 $\alpha$, VEGF, and MMP-9 and upregulation of HO-1. J Ocul Pharmacol Ther 29: 539-549, 2013.

46. Li Z, Wang Y, Man RY and Vanhoutte PM: Upregulation of heme oxygenase-1 potentiates EDH-type relaxations in the mesenteric artery of the spontaneously hypertensive rat. Am J Physiol Heart Circ Physiol 305: H1471-H1483, 2013.

47. Imenshahidi M, Hosseinzadeh $\mathrm{H}$ and Javadpour Y: Hypotensive effect of aqueous saffron extract (Crocus sativus L.) and its constituents, safranal and crocin, in normotensive and hypertensive rats. Phytother Res 24: 990-994, 2010.

48. Xu GL, Qian ZY, Yu SQ, Gong ZN and Shen XC: Evidence of crocin against endothelial injury induced by hydrogen peroxide in vitro. J Asian Nat Prod Res 8: 79-85, 2006.
49. Chen L, Luo ZK, Peng GP, Li XH, Liu L, Sheng XB and Wang ZG: The cardiac systolic and diastolic effects of genipin-1- $\beta$-D-gentiobioside in the experimental heart failure. Pharm Clin Chinese Mater Med 29: 39-41, 2013 (In Chinese).

50. Wang ZC, Yang XL, Zhang K and Xiao P: Research on pharmacological activities of gardenoside. J Henan Univ Sci Technol Med Sci 30: 159-160, 2012

51. Pang $\mathrm{H}, \mathrm{Han} \mathrm{B}, \mathrm{Yu} \mathrm{T}$ and Peng $\mathrm{Z}$ : The complex regulation of tanshinone IIA in rats with hypertension-induced left ventricular hypertrophy. PLoS One 9: e92216, 2014.

52. Wang HT, Liu CF, Tsai TH, Chen YL, Chang HW, Tsai CY, Leu S, Zhen YY, Chai HT, Chung SY, et al: Effect of obesity reduction on preservation of heart function and attenuation of left ventricular remodeling, oxidative stress and inflammation in obese mice. J Transl Med 10: 145, 2012.

53. Kolwicz SC, MacDonnell SM, Renna BF, Reger PO, Seqqat R, Rafiq K, Kendrick ZV, Houser SR, Sabri A and Libonati JR: Left ventricular remodeling with exercise in hypertension. Am J Physiol Heart Circ Physiol 297: H1361-H1368, 2009.

54. Favaloro B, Allocati N, Graziano V, Di Ilio C and De Laurenzi V: Role of apoptosis in disease. Aging (Albany NY) 4: 330-349, 2012.

55. Liu Y, Wang S, Wang C, Song H, Han H, Hang P, Jiang Y, Wei L, Huo R, Sun L, et al: Upregulation of $\mathrm{M}_{3}$ muscarinic receptor inhibits cardiac hypertrophy induced by angiotensin II. J Transl Med 11: 209, 2013.

56. Shi XC, Liu W, Wang J and Zhao YQ: Effect of the Tianma Gouteng regulating the protein expression of Bax and Caspase-3 of myocardial tissue in spontaneously hypertensive rats. Tianjin J Tradi Chinese Med 33: 354-357 (In Chinese).

57. Jing X, Chen SS, Jing W, Tan Q, Yu MX and Tu JC: Diagnostic potential of differentially expressed homer1, IL-1 $\beta$, and TNF- $\alpha$ in coronary artery disease. Int J Mol Sci 16: 535-546,0 2014.

58. Zhu XY, Chade AR, Krier J, Daghini E, Lavi E, Guglielmotti A, Lerman A and Lerman LO: The chemokine monocyte chemoattractant protein-1 contributes to renal dysfunction in swine renovascular hypertension. J Hypertens 27: 2063-2073, 2009.

59. Fu L, Das B, Mathew S and Shi YB: Genome-wide identification of Xenopus matrix metalloproteinases: Conservation and unique duplications in amphibians. BMC Genomics 10: 81, 2009.

60. Raffetto JD and Khalil RA: Matrix metalloproteinases and their inhibitors in vascular remodeling and vascular disease. Biochem Pharmacol 75: 346-359, 2008.

61. Givvimani S, Munjal C, Tyagi N, Sen U, Metreveli N and Tyagi SC: Mitochondrial division/mitophagy inhibitor (mdivi) ameliorates pressure overload induced heart failure. PLoS One 7: e32388, 2012.

62. Li W, Mata KM, Mazzuca MQ and Khalil RA: Altered matrix metalloproteinase-2 and -9 expression/activity links placental ischemia and anti-angiogenic sFlt-1 to uteroplacental and vascular remodeling and collagen deposition in hypertensive pregnancy. Biochem Pharmacol 89: 370-385, 2014.

63. Kluknavsky M, Balis P, Puzserova A, Radosinska J, Berenyiova A, Drobna M, Lukac S, Muchova J and Bernatova I: (-)-Epicatechin prevents blood pressure increase and reduces locomotor hyperactivity in young spontaneously hypertensive rats. Oxid Med Cell Longev 2016: 6949020, 2016.

64. Belo VA, Parente JM, Tanus-Santos JE and Castro MM: Matrix metalloproteinase (MMP)-2 decreases calponin-1 levels and contributes to arterial remodeling in early hypertension. Biochem Pharmacol 118: 50-58, 2016.

65. Akinrinde AS, Oyagbemi AA, Omobowale TO, Asenuga ER and Ajibade TO: Alterations in blood pressure, antioxidant status and caspase 8 expression in cobalt chloride-induced cardio-renal dysfunction are reversed by Ocimum gratissimum and gallic acid in Wistar rats. J Trace Elem Med Biol 36: 27-37, 2016. 